WORKING PAPER NO. 167

\title{
POST-MFA ADJUSTMENTS IN INDIA'S TEXTILE AND APPAREL INDUSTRY: EMERGING ISSUES AND TRENDS
}

Meenu Tewari

JULY 2005
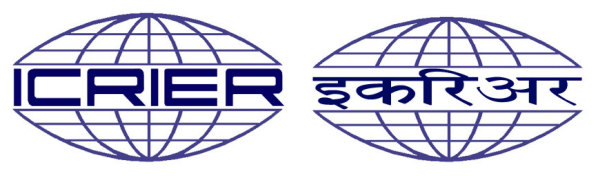

INDIAN COUNCIL FOR RESEARCH ON INTERNATIONAL ECONOMIC RELATIONS Core-6A, 4th Floor, India Habitat Centre, Lodi Road, New Delhi-110 003 Website: www.icrier.org 


\section{POST-MFA ADJUSTMENTS IN INDIA'S TEXTILE AND APPAREL INDUSTRY: EMERGING ISSUES AND TRENDS}

Meenu Tewari

JULY 2005

The views expressed in the ICRIER Working Paper Series are those of the author(s) and do not necessarily reflect those of the Indian Council for Research on International Economic Relations (ICRIER). 


\section{Contents}

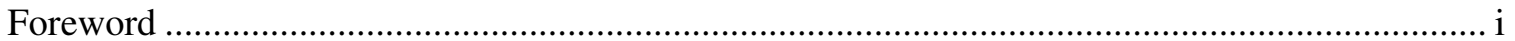

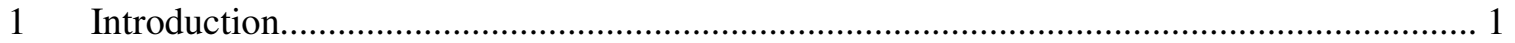

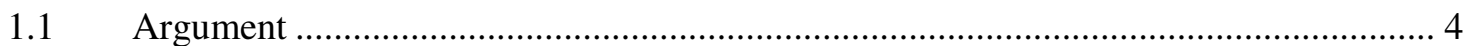

2 Global sourcing: the growing 'stickiness' of market access.............................................. 5

3 A non-traditional trajectory of global integration: The Indian case...................................... 7

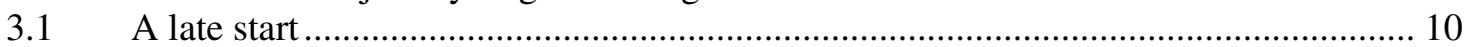

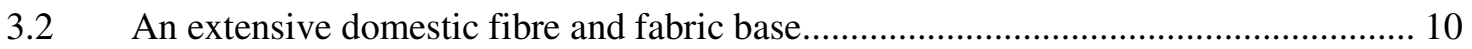

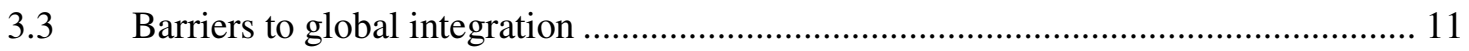

3.4 Policy turnaround: deregulation and external sector reforms ................................... 14

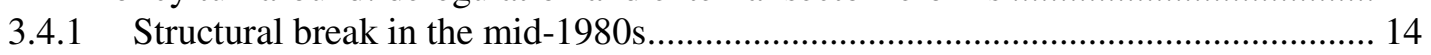

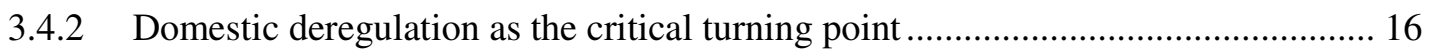

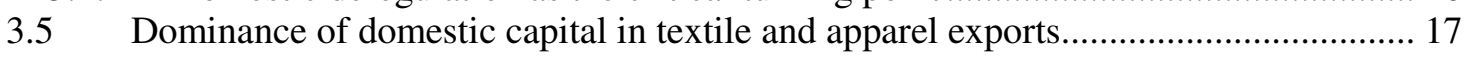

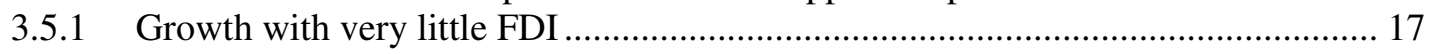

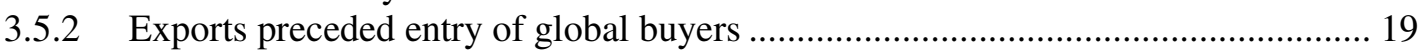

3.5.3 Integration without Regional Trade Agreements.................................................... 19

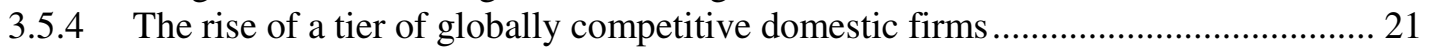

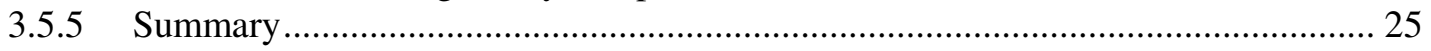

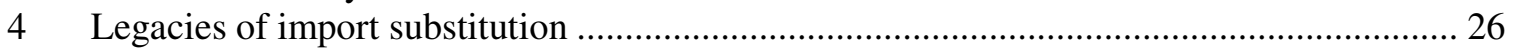

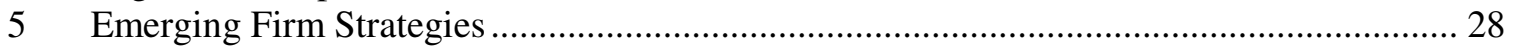

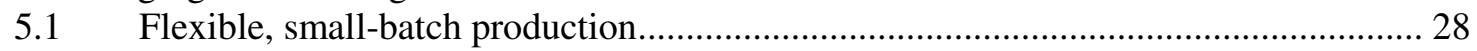

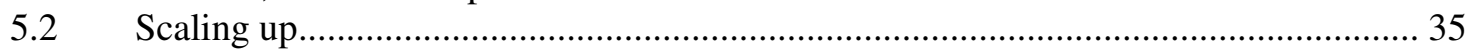

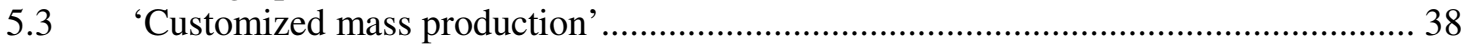

$6 \quad$ Blurring of the boundaries between domestic and export markets ...................................... 44

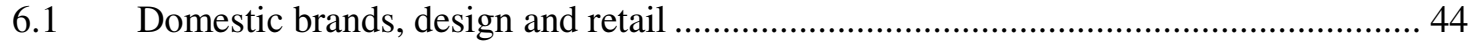

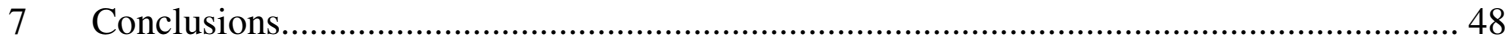

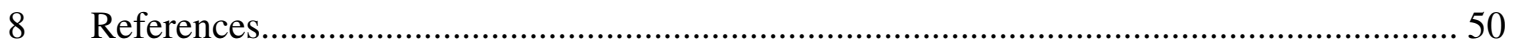

\section{$\underline{\text { Tables }}$}

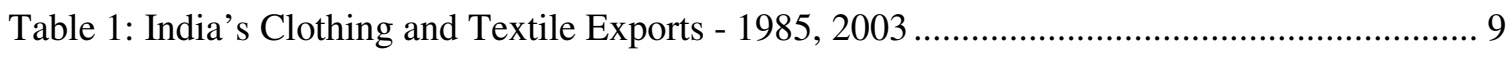

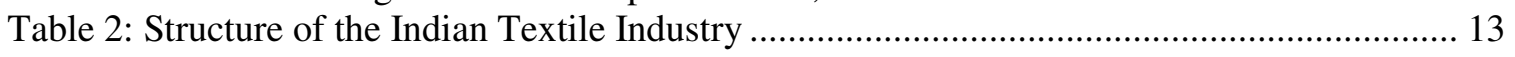

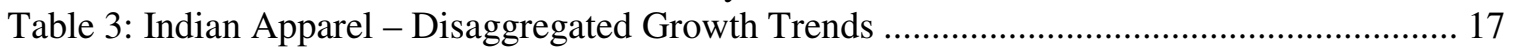

Table 4: India's Leading Textile and Apparel Companies (2004) - Ranked by Market

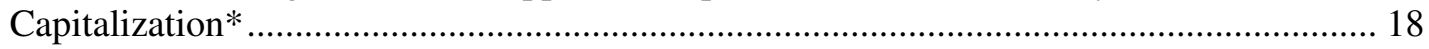

Table 5: Growth Rates of the top 15 Apparel Exporters between 1993 and 2003 ...................... 21

Table 6: Productivity Levels of Apparel Firms (Number of pieces per day), 1993 ..................... 27

Table 7: Comparative Labor Costs in the Apparel Industry, 2000............................................ 28

Table 8: Normalized Unit Values for India's Leading Apparel Exports to the World (CPI base = 1995)

Table 9: Post-MFA Growth of India's Apparel Exports to the US, January to May 2005 (Selected

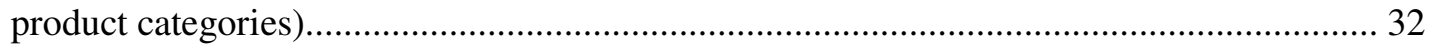

Table 10: Post-MFA Growth of India's Textile Exports to the US - Selected Categories ........... 39 


\section{$\underline{\text { Figures }}$}

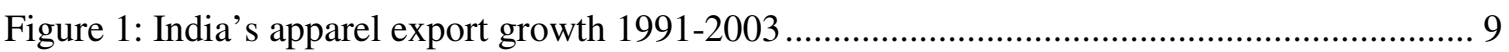

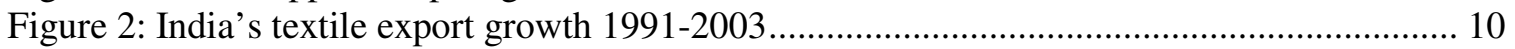

Figure 3: Growth of India's textile and apparel exports showing structural break in 1985-86 ..... 15

Figure 4: Capital labor ratio - Indian Textile industry 1974-1998 ............................................ 23

Figure 5: Ratio of plant and machinery to sales in a sample of 77 textile and apparel firms 19892003.

Figure 6: Decomposition of product segment shares in India's textile and apparel exports 19922003

Figure 7: India and China's unit values (Inflation adjusted dollars per unit) .............................. 31

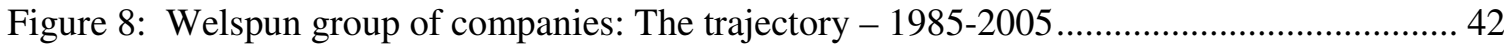




\section{Foreword}

India, a late integrator in the global market for clothing, has followed a path to integration that is quite different from the experience of some of its major competitors. Unlike China, Mexico, Eastern Europe and other South Asian countries, India's recent surge in clothing exports has occurred despite the lack of major FDI in textile and apparel, or entry into preferential regional trade agreements with buyer countries, or any significant direct role of global buyers. Arguing that changes in domestic policy and in the structure of domestic demand throughout the 1980s and 1990s played an important role in triggering new growth in India's textiles and apparel exports, and reshaping the capabilities of local firms, this paper examines three features of India's recent integration into global clothing markets: the striking emergence of design as a source of comparative advantage in Indian apparel, the growing importance of outward-bound investment by Indian clothing firms in recent years, and the powerful new role that retail is playing in organizing the Indian domestic market, driven in part by surging consumer demand from entirely new mid-market youth segments associated with the country's IT-BPO boom.

Dr. Arvind Virmani Director \& CE ICRIER

July 2005 


\section{Introduction $^{1}$}

The final phase-out of the Multi-fiber Arrangement (MFA) ${ }^{2}$ and the system of quotas that has governed the global trade in textiles and apparel for the last forty-two years, has significantly altered the institutional rules of trade in the textile and clothing industry. With the elimination of all remaining quotas on apparel from January 12005 , the textile and clothing sector is now fully integrated into the regulatory framework of the General Agreement on Tariffs and Trade (GATT) of the World Trade Organization (WTO). Buyers are, thus, free to source textile and apparel in any amount from any country; suppliers are similarly free to export as much product as they are able, subject only to a system of national tariffs (see Weil 2004, Abernathy et. al. 2004). As global competition intensifies under the new quota-free trading regime, countries are bracing for major changes in the structure of sourcing and apparel supply worldwide.

There is widespread expectation that the removal of quota restrictions will lead to a substantial consolidation of global supply networks, creating winners and losers (Gereffi 2004, US ITC 2004, Nordås (WTO) 2004, Knappe 2003). The widely held assumption is that large, low cost supplier countries, such as China, India, and Mexico with stable supply networks, experience in exporting, well-developed capacities for scaling up and the ability to offer a full bundle of services will benefit from the postMFA reorganization of the global trade in textiles, while smaller countries that had benefited from the limited but guaranteed access to industrial markets under quotas, may well lose out. Already, commentators are pointing to how small countries like Mauritius are witnessing an erosion of Foreign Direct Investment (FDI) in apparel, with overseas

\footnotetext{
${ }^{1}$ I thank Gary Gereffi, Arvind Virmani, Danish Hashim, Arpita Mukherjee and participants at three recent conferences - the global networks conference at Yale University, the workshop on 'The End of Global Quotas' at the Labor and Worklife Program at Harvard Law School, and the 'Clothing Europe' workshop at UNC - for valuable comments on earlier versions of this paper. Karan Singh provided excellent research assistance. The arguments made herein and all errors of fact and interpretation are my responsibility. The author can be contacted at mtewari@unc.edu.

${ }^{2}$ The Long Term Agreement Regarding International Trade in Cotton Textiles (LTA) was first negotiated in 1962. It was replaced by the Multi Fiber Arrangement (MFA) in 1974, which in turn was replaced in its terminal phase in 1994, and coincident with the rise of the WTO, by the Agreement on Textiles and Clothing (ATC) from 1995 to 2005.
} 
investors beginning to pull out. ${ }^{3}$ Most analysts project that China will emerge as the likely "supplier of choice" for the world's largest retailers and buyers after quotas -followed by other large suppliers, such as India, selected South-East Asian countries, Eastern Europe, Mexico and Turkey (US International Trade Commission 2004, WTO (Nordås) 2004, Knappe 2003). ${ }^{4}$

A widely cited study by the WTO, for example, uses models based on relative prices, cost competitiveness and the degree of pre-abolition quota-restrictiveness faced by individual countries to project that China's post-MFA share in the US apparel market could triple from its current share of $16 \%$ to as much as $50 \%$ after 2005, and India's could quadruple from about $4 \%$ to $15 \%$ after the removal of quotas (Nordås 2004). This finding suggests, on the face of it, that China and India's combined export share in the US apparel market could be a staggering $65 \%$ post-MFA, compared to their combined share of 20\% in 2003 (Nordås, WTO 2004:30, Financial Times, July 19, 2004). Though the actual dynamics of adjustment are likely to be far more uncertain and contingent upon a much wider set of political and institutional processes than these models suggest, ${ }^{5}$ it is little wonder that countries are worried about their place in the international division of labor in textiles and clothing as quotas are phased out.

These concerns are exacerbated by the importance of textiles and apparel to the employment base and economic structure of most countries. Though portrayed as a classic sunset industry, the textile and apparel sector is one of the largest employers in both developed and developing countries, often serving as the first point of entry for large numbers of unskilled workers (see Berger, Gartner and Karty 1997). For many countries, from Bangladesh to Lesotho to El Salvador where clothing exports respectively constitute

\footnotetext{
${ }^{3}$ See Thomas 2005, Afrol News 2004, Bradsher 2004. Also see Knappe 2003, US ITC 2004, Gibbon 2000 and Palpaceur et. al. in press, for a broader discussion on the tightening prospects for small producers in accessing global markets after quotas. In an ironic twist, with the recent return of many Mauritius-based India joint ventures back to India, Mauritius topped the list of countries with FDI in India in March 2005.

${ }^{4}$ Based on a cross country comparison of suppliers that benefited most from the third stage of the liberalization of quotas under ATC in January 2002, Knappe (2003) for example found that compared to other countries China was the only country to have substantially increase its exports across the board, in all the (seven) product categories that the US had liberalized, relative to other countries who improved their export performance in only some of the liberalized categories, if at all.

${ }^{5}$ See Smith et. al. 2004, Begg et. al. 2003, and Abernathy et. al. 2004)
} 
up to $86 \%, 94 \%$, and $60 \%$ of total merchandise exports (USITIC 2004: 1-4), the textile and apparel sector is a dominant contributor to industrial output, foreign exchange, employment and national development. As competition escalates in this sector at home and abroad, a central policy concern among suppliers worldwide is how firms and governments can shore up the competitiveness of their textile and apparel sectors in this altered institutional environment to maintain if not enhance, their place in the global market. ${ }^{6}$

This paper uses the case of India, which has been repeatedly cited as a major potential beneficiary of the post-quota regime, to examine the emerging pathways of adjustment in the global textile and clothing industry. Famously inward-looking till the 1980s, the Indian textile and clothing industry has become increasingly integrated into global markets since the late-1980s and 1990s, emerging as one of the top ten global exporters of textiles and clothing after 1998. India's apparel exports grew at an average compound rate of 22\% per year throughout the 1980s (Chatterjee and Mohan 1993), and by about $13 \%$ in the 1990s (United Nations Statistical Division, 2005). By 2003, India exported more than $\$ 13.5$ billion worth of textile and apparel, up fifteen-fold from the $\$ 0.9$ billion it exported in 1985, when apparel exports were just taking off (United Nations Statistical Division, 2005). This export growth, though slow in comparison to exporters like China, is impressive because it occurred despite the persistence of many of the factors that observers have cited as shackling Indian productivity in textiles and apparel: technological obsolescence, fragmented capacities, low scales of operation, lack of an exit policy, and rigid labor laws. Drawing on findings from three rounds of fieldwork in India's textile and apparel industry carried out between 2000 and 2005, this paper examines the micro-foundations of India's rapid recent incorporation into the

\footnotetext{
${ }^{6}$ Witness for example, the intense lobbying by powerful US textile interests for countervailing measures, targeted protections and expedited import reviews against low-cost competitors, especially China, and the decision in March 2005 by the US government to step up monitoring of US textile imports (US, ITC 2004, Blustein 2004, TC-Trade 2004, Crutsinger 2005, Financial Express 2005); the EU has already built in textile safeguards (against China) for the next five years (CEC 2004), and China on its part, has declared its intention to impose voluntary restraints on exports so as to make the transition to the world without quotas more predictable (Blustein 2004, TC-Trade 2004). At the same time, smaller countries who experienced high output and export growth in apparel under quotas, are urgently looking for ways to preserve the viability of their suppliers under the new rules of trade.
} 
global clothing and textile market, focusing on how Indian firms have become inserted within global textile and apparel networks in recent years, and how this position is changing as the rules of global trade change.

\subsection{Argument}

The paper's main findings are twofold. First, it shows that India's path to global integration in textiles and apparel differs from the path of its proximate competitors, in that it occurred without significant FDI, or entry into regional Free Trade Agreements (such as NAFTA) or deep insertion into dominant global clothing supply chains. Rather, at the vanguard of India's growing global presence are a tier of highly competitive domestic firms that were able to restructure themselves during the deregulation of the textile and apparel industry in the mid-1980s (which first triggered export growth in Indian apparel, as distinct from the trade liberalization of the early 1990s), and build new ties with buyers and suppliers at home and abroad in the late 1980s and early 1990s. The external sector reforms of 1991 deepened this process of integration that began in the mid-1980s.

Second, the paper argues that the same legacies that resulted in India's slow integration into the global textile and apparel market, have also, inadvertently produced legacies that could, if nurtured well, move the Indian apparel industry toward a higher value-added, design-intensive path of upgrading and adjustment —in addition to scaling up. This emerging pattern resembles the experience of countries like Italy and Hong Kong more than it resembles the experience of other major apparel exporters who, like India, have low wages and low production costs and concomitant factor endowments.

The rest of the paper proceeds as follows. After a brief framing of the institutional context and market conditions within which the phase-out of textile quotas has taken place, section three examines the structure of India's apparel and garment industry and its emerging place in the global market. Section four focuses on firm strategies in the years leading up to the dissolution of quotas to discuss, in section five, three rather unexpected themes that are shaping the post-MFA response of the Indian 
textile and clothing industry: the striking emergence of design as a source of comparative advantage in Indian apparel, the growing importance of outward-bound investment by Indian clothing firms in recent years, and the powerful new role that retail is playing in organizing the Indian domestic market, fuelled in part by surging demand from new market segments associated with the country's booming IT and BPO (Business Process Outsourcing) sectors. The final section concludes.

\section{Global sourcing: the growing 'stickiness' of market access}

As countries search for ways to strengthen their textile and clothing base in the face of intensified quota-free competition, at least three issues complicate adjustment, blunting in each case the freer access to markets that the removal of quotas ostensibly provides suppliers. First, firms do not simply export into undifferentiated economic space. As an extensive literature has begun to document, global trade in the apparel industry is increasingly organized by powerful buyers, mainly large retailers and branded merchandisers (such as Wal Mart, Gap, and Nike) who coordinate the design, production, and distribution of apparel within highly mobile, globally dispersed clothing value chains (Gereffi 1994, 1999, Bair and Gereffi 2001, Gereffi and Kaplinksy 2001, Feenstra 1998, Dicken 1998, Humphrey and Schmitz 2000). Trade, in this framework, is "sticky," because market access is often contingent upon suppliers' entry into increasingly concentrated clothing chains and production networks. After the removal of quotas, when buyers are no longer required to distribute their orders across countries, most observers expect entry barriers into these chains to tighten even further (USITC 2004:2-7, Gereffi 2004, Palpaceur et. al 2005).

This implies that after the dissolution of quotas, access to major markets may in fact become more constrained as global buyers restructure their sourcing patterns towards highly competent 'full-package' suppliers. These suppliers would have the capability to not only provide made-to-order assembly operations, but to flexibly accommodate variability in design, local and proximate sourcing of high quality fabrics and accessories,

and handle both, small-batch as well as large volume production cost-effectively (Gereffi 
2004, Gibbon 2004, Palpaceur et. al. 2005, Smith et. al. 2004). Market access, in this view then, depends not only on low costs, or freer trade, but on the ability of local suppliers to meet increasingly stringent buyer demands for quality, customization, and short lead times (i.e., full package supply), in addition to keeping costs low.

Second, the emergence of new considerations in sourcing, such as the importance of replenishment and short turn-around times in the sourcing of time-sensitive, quickselling items (such as jeans and T-shirts), has added further stickiness to the flow of apparel and textile trade, reinforcing the importance of location in supplier choice (Abernathy et. al. 1999, Abernathy, Volpe and Weil, 2004, Nordås 2004, Palpaceur et. al. 2005). Acting in a direction opposite to the dynamic of extensive outsourcing within globally dispersed production networks, the rise of 'lean-retailing, ${ }^{7}$ and the adoption of sophisticated information technologies to manage the sourcing of replenishment-intensive items, is privileging speedy delivery and proximity over considerations of price. (For example, Mexico or the Caribbean basin, despite their higher production costs may be preferred by US buyers over lower cost China for the supply of certain items.) These new trends are making sourcing patterns sticky, and serving to fragment the geography of apparel production into ever-finer regional sub-divisions (see Abernathy, Dunlap, Hammond and Weil,1999, Nordås 2004).

These spatial divisions are being further reinforced by the rise of regionalism within world trade, and the proliferation of Regional Free Trade Agreements. By privileging some countries over others in terms of tariff-free market entry, regional trade agreements $^{8}$ are segmenting market-access on the basis of differentially applicable tariff levels. In a world without quotas, where tariffs (or their absence, and of non-tariff barriers) assume much greater power in shaping market access, regional trade agreements can produce highly differentiated and uneven geographies of apparel sourcing and

\footnotetext{
${ }^{7}$ Abernathy, et. al. 1999.

${ }^{8}$ These include agreements that have emerged around every major market: NAFTA, CBI, AGOA, CAFTA around the US, the expansion of the European Union and concessionary bilateral agreements and customs unions between the EU and its regional suppliers in North Africa, the Mediterranean basin, ECE and Turkey.
} 
supply. At a time when the dissolution of quotas is restructuring the rules of trade in textiles and clothing, and the emergence of preferential regional trade agreements and new forms of sourcing are complicating market access, it is important to understand the diversity of ways in which suppliers are becoming incorporated into global markets and the varied pathways of upgrading that are emerging.

In the following sections we examine India's recent integration into the global apparel market to explore one such pathway of global insertion and upgrading.

\section{India's trajectory of global integration}

Like in many countries, the textile industry has played a "leading sector" role in the Indian economy. It is one of India's oldest and most deeply rooted manufacturing sectors, and a major employer. The textile and clothing sector provides direct employment (formal and informal) to an estimated 38 million people nationwide ${ }^{9}$ (compared to the estimated 1.2 million employed in the IT sector, and about 650,000 in the booming Business Process Outsourcing industry (Ministry of Textiles, Annual Report, 2004, Nasscom 2005). The industry contributes 7\% to Gross Domestic Product, ${ }^{10} 14 \%$ to industrial output and an estimated $18 \%$ to industrial employment. (Ministry of Textiles, 2004, Hashim 2005). Moreover, with very low import intensities of only $1.2 \%$ (Verma 2002, Ministry of Textiles, 2005) - the textile and clothing industry is one of India's largest net earners of foreign exchange, contributing about $21 \%$ of India's export earnings annually (Ministry of Textiles, 2005, WTO statistics 2005).

In 2003, the latest year for which data are available, India exported $\$ 13.5$ billion in textiles and apparel, ${ }^{11}$ more than double the amount ( $\$ 5.9$ billion) it exported ten years ago. Its apparel exports, of $\$ 6.6$ billion, ranked $8^{\text {th }}$ in the world market that year (behind

\footnotetext{
${ }^{9}$ The figures are for 2003-04 from the Ministry of Textiles.

${ }^{10}$ The standard figure for the textile industry's contribution to GDP is 4\%; however, working backwards from actual export figures to GDP shares, we estimate the share of textiles and apparel in GDP to currently be closer to $7 \%$ than $4 \%$.
} 
Mexico and France), and its textile exports of $\$ 6.8$ billion ranked ninth (after France and just ahead of Japan). By way of comparison, China, the top ranked exporter of apparel and textiles exported $\$ 52$ billion worth of apparel that year (eight times more than India) and $\$ 27$ billion in textiles (four times India's exports). Mexico, ranked tenth, exported $\$ 7.3$ billion in apparel and $\$ 1.2$ billion in textiles in 2003. The principal markets for Indian textile and apparel exports are the US and the European Union (EU-15) - the two largest erstwhile quota regimes, which together accounted for $83 \%$ of India's total clothing exports and $52 \%$ of its textile exports in $2003 .^{12}$ While the EU, with a $47 \%$ share in India's apparel exports (and a 29\% share in textiles) is India's largest regional market for clothing and textiles, the US has emerged as the fastest growing, single largest destination for Indian textile and apparel in recent years. In 2003 it procured 36\% of India's apparel and $23 \%$ of its textile exports. (See

Figure 1 and Figure 2). Of all the major importing countries, India's presence is weakest in the Japanese market. Japan procured only 1\% of India's apparel exports and $3 \%$ of its textiles in 2003 (WTO statistics, 2005). ${ }^{13}$ While India's apparel exports are highly concentrated in the EU and US, its textile markets are more diversified -- nearly half $(48 \%)$ of India's textile exports were directed to countries outside the US and EU in 2003, compared with only 17\% in the case of apparel (see Table 1). Apart from the US, UK, Germany and Italy, a mix of middle-income countries and emerging markets such as UAE (United Arab Emirates), South Korea, Turkey, Bangladesh and Hong Kong are among India's top ten markets for textiles (in that order). Overall, India's share in the $\$ 408$ billion world clothing and textile market, though small - a very modest 3.3\% compared especially with China's spectacular $20 \%$-- has been rising steadily in the last

\footnotetext{
${ }^{11}$ By way of comparison, India's fastest growing sector, IT and IT enabled services, had $\$ 9.9$ billion in exports in the same year (Nasscom, 2005:26).

${ }^{12}$ Though the EU and US were always important markets for India's exports, for a brief period in the 1960s and 1970s - during the apogee of the cold war and amid tensions between the US and India leading up to the Bangladesh war in 1971 - the former Soviet Union became India's major market. Till 1962 the former Soviet Union had only a 10\% share in India's apparel exports. In 1965 this shot up to 40\%, then to $70 \%$ in 1967 and to 53\% in 1970, before falling back to $19 \%$ in 1974 and 10\% in 1978 (UN Trade Statistics cf. Chatterjee and Mohan 1993:M-99). The devaluation of the rupee in 1966 could also be a reason for the rather steep dampening of the dollar-denominated share of US and EU's imports relative to the rupee-trade with the former Soviet Union.

${ }^{13}$ By contrast, $30 \%$ of China's apparel exports and $48 \%$ of its textile exports are consumed by Japan, which is China's largest market in textiles and clothing.
} 
two decades - growing from $1.5 \%$ in 1980 to $2.3 \%$ in 1990 and $3.3 \%$ in 2003 (UN Statistical Division, 2005, Ramaswamy and Gereffi 1998).

Table 1: India's Clothing and Textile Exports - 1985, 2003

(US\$ Million and percentage)

\begin{tabular}{|c|c|c|c|c|c|c|c|c|}
\hline & \multicolumn{5}{|c|}{ Clothing Exports } & \multicolumn{3}{|c|}{ Textile Exports } \\
\hline & \multicolumn{2}{|c|}{ Value } & \multicolumn{2}{|c|}{ Share (\%) } & \multirow{2}{*}{$\begin{array}{c}\% \\
\text { Change } \\
1985-03 \\
\end{array}$} & & \multirow{2}{*}{$\begin{array}{c}\text { Value } \\
2003 \\
\end{array}$} & \multirow{2}{*}{$\begin{array}{c}\text { Share } \\
2003 \\
\end{array}$} \\
\hline & 1985 & 2003 & 1985 & 2003 & & & & \\
\hline EU-15 & 332 & 3012 & 36 & 47 & $807 \%$ & EU-15 & 1888 & 29 \\
\hline US & 263 & 2309 & 29 & 36 & $778 \%$ & US & 1528 & 23 \\
\hline Japan & 25 & 95 & 3 & 1 & $280 \%$ & Japan & 176 & 3 \\
\hline Fmr USSR & 172 & 0 & 19 & 0 & & $\begin{array}{l}\text { Fmr USSR } \\
\text { Rest of the }\end{array}$ & 0 & 0 \\
\hline Rest of the World & 121 & 1146 & 13 & 16 & $847 \%$ & World & 3259 & 45 \\
\hline Total & 914 & 6562 & 100 & 100 & $618 \%$ & Total & 6851 & 100 \\
\hline
\end{tabular}

Source: WTO Statistics

Figure 1: India's apparel export growth 1991-2003

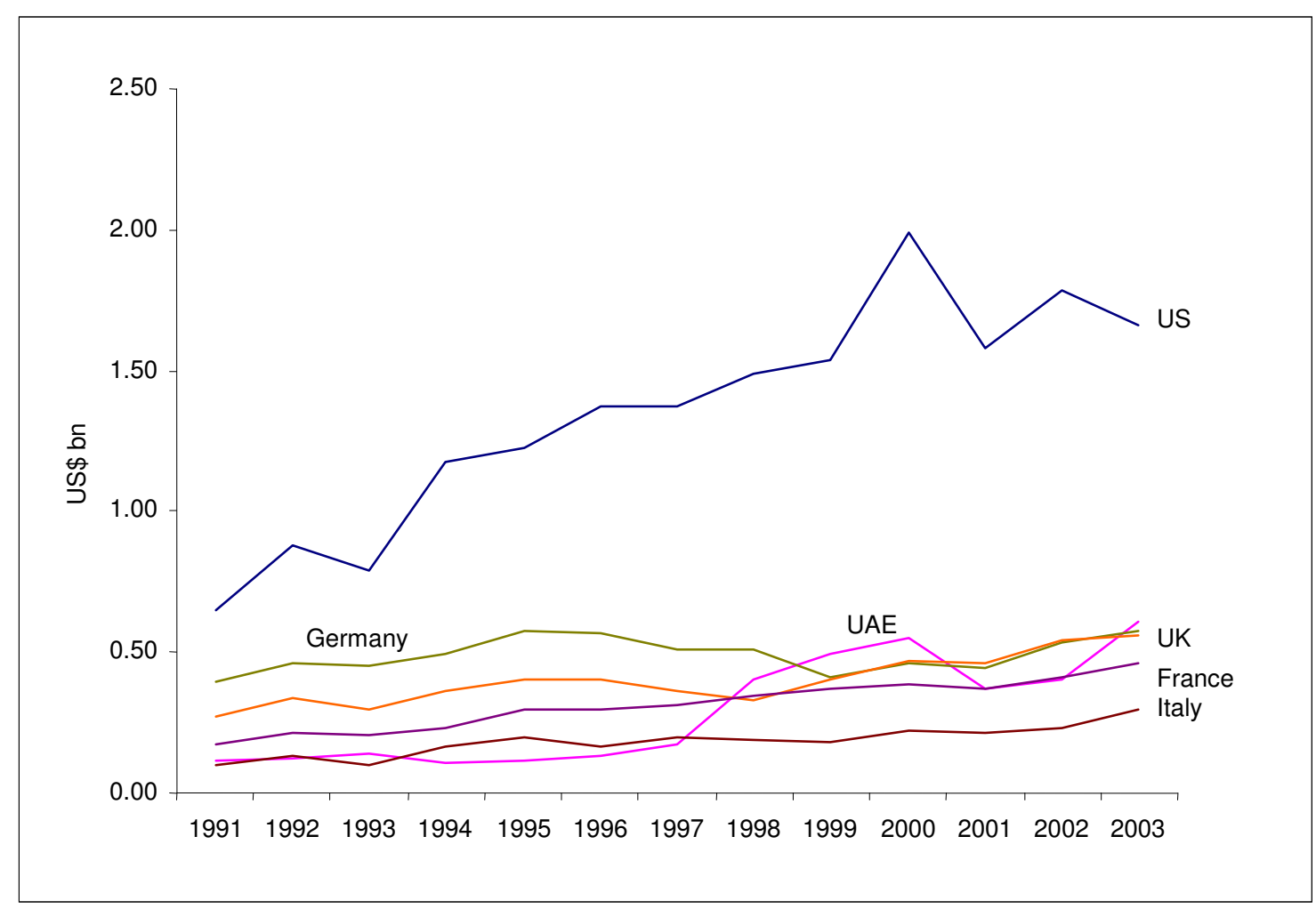

Source: UN Statistical Division 
Figure 2: India's textile export growth 1991-2003

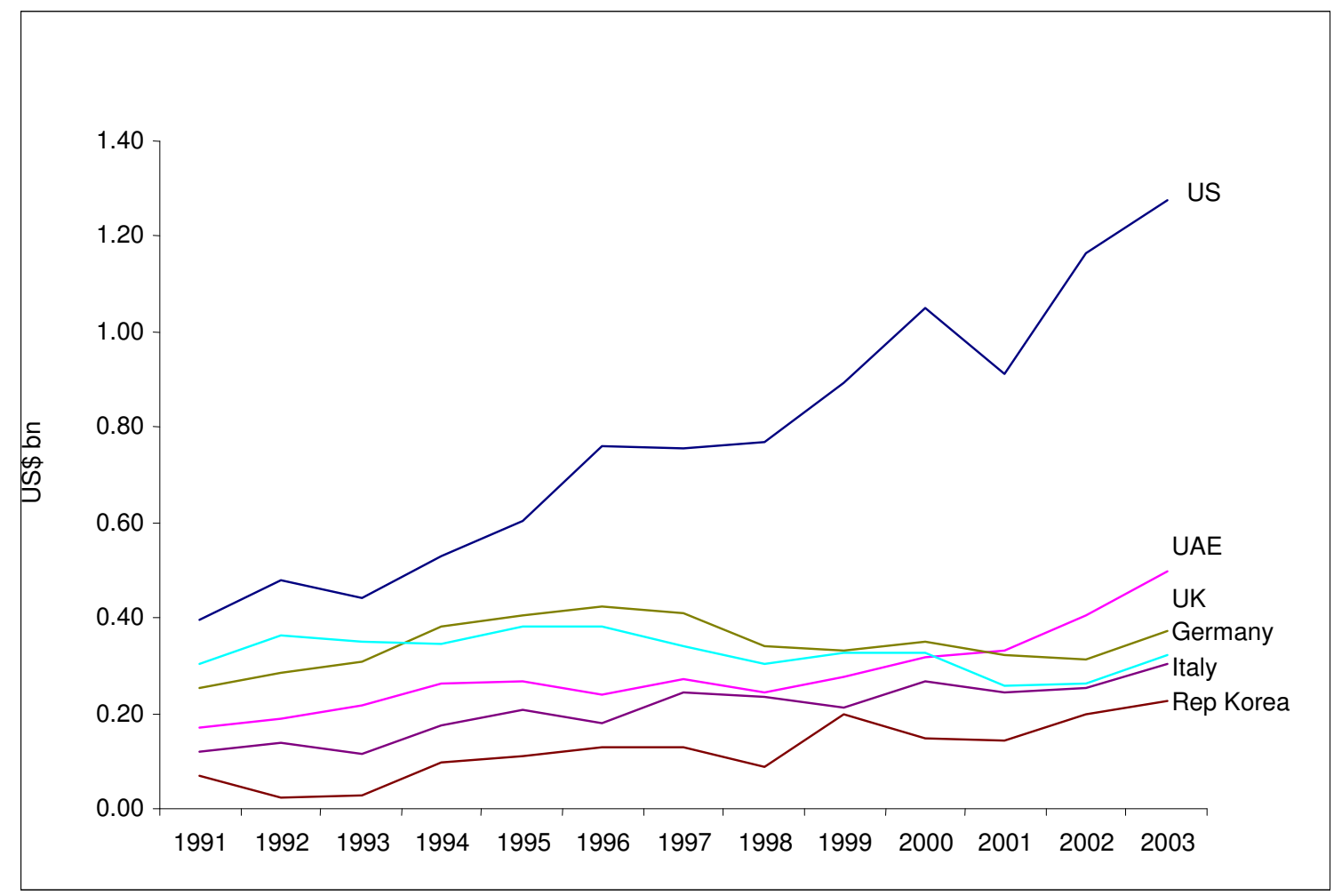

Three features are striking when one compares India with other countries that have emerged as successful exporters of garments and textiles in recent years.

\subsection{A late start}

First, India's apparel exports are of relatively recent vintage, having taken off only in the mid-1980s, well after the first and second wave of global outsourcing in the 1970s and 1980s established strong apparel export platforms across East Asia, Latin America, China and Southern Africa. Till the 1960s and 1970s India was mainly an exporter of textiles, it barely had any export-oriented garment production. The linkages of India's apparel industry with global clothing chains are therefore shallower and relatively recent, a point we return to momentarily.

\subsection{An extensive domestic fibre and fabric base}

Second, India's apparel exports are embedded within a strong domestic textile industry. Unlike many import substituting countries whose textile and clothing sectors 
originated with export-oriented apparel assembly in the 1970s and 1980s, gradually linking backwards into textiles in a small number of cases, the development of India's textile industry preceded the rise of its apparel sector. India has an extensive fibre baselargely in cotton - and though organized in much smaller average unit sizes compared to firms in other supplier countries, its production capacities and raw material availability are second only to China's. With a $13 \%$ share in the global production of textile fibres, India is the third largest global producer of cotton yarn, the second largest producer of silk, and the $5^{\text {th }}$ largest producer of synthetic fiber/yarn. It is one of a few developing countries today (along with China, Turkey, parts of Eastern Europe and Pakistan) with a fully developed textile value chain extending from fibre to fabric to garment exports (illustrated also by very low import intensities (1.2\%) of its apparel exports). The presence of a domestic textile industry - a legacy of the countries vast capabilities in cotton production and the government's efforts to harness this abundant raw material base to generate employment and ensure adequate availability of cloth for domestic consumers-is emerging as a major advantage for India's apparel exports. As India's apparel firms compete for market share in a world where timely deliveries, low costs, variability and quality are critical, the proximate availability of good quality textiles is a major benefit as some have noted (Gereffi 2004, Berger and Lester 1997).

\subsection{Barriers to global integration}

Third, India has integrated relatively slowly in the global apparel and textile market relative to many of its comparators. Despite large raw material availability and extensive production capacities, second only to China's, its share in the global market in textile and clothing has risen only slowly, from $1.5 \%$ in 1975 to only $3.3 \%$ in 2003 compared to China's rapid increase of world market share in textiles and apparel from $8.9 \%$ in 1990 to $20 \%$ in 2003 . Till the 1970 s and early1980s, when apparel production first began to be off-shored to developing countries across East Asia, Latin America, China and Southern Africa, India's apparel exports were miniscule - amounting to less than $2 \%$ of total exports (with a 0.6 percent share in the global apparel market in 1970 compared to Hong Kong's 11\% market share that year, for example). 
This slow global integration resulted, in part, from the highly restrictive quotas that constrained India's export volumes throughout the late 1970s, 1980s, and 1990s (Kathuria, Martin, and Bharadwaj 2001, Verma 2002)_given that a bulk of India's apparel exports were historically directed to countries with the most stringent quotas the US and EU - in comparison with countries like China, whose export markets were much more diversified and less dependent on quota countries. In 1985 when India's apparel exports first took off, $65 \%$ of its apparel exports were being absorbed by the US and EU - the biggest quota regimes, and by 2003 this figure had risen to a staggering $83 \%$. By contrast, China's combined apparel exports to the US and EU were only $42 \%$ in 1985 and had risen marginally to $47 \%$ by 2003 (Data are for SITC 84, Rev. 1 and 3). Non-quota countries like Japan and Hong Kong were important markets for China historically - together accounting for 32\% of China's exports in 1985. By 2003, Japan had emerged as China's single largest textile and apparel market, absorbing fully $30 \%$ of China's apparel exports and 48\% of its textile exports in 2003 (UN Statistics 2005 for SITC 84 and 65 respectively).

While quota constraints have played a role in slowing India's export volumes in certain product categories since the mid-1970s, India's slow integration in global textile and apparel markets reflects mostly the historically strong domestic focus of Indian textile policy. Throughout the late 1960s, 1970s and early 1980s the Indian state used a variety of regulatory mechanisms and policies to orient the textile and apparel industry toward the domestic market, and shape the structure of the industry in key ways. Using a strict licensing regime (that required firms to seek permission from the government before establishing new operations and expanding capacity), reservation policies (that reserved key segments of the value chain-most notably apparel-for production in the small scale sector), and labor laws (which restricted exit and retrenchment heavily, especially after 1976), the government controlled the size, location, scale, growth and expansion of the textile and apparel industry throughout this period. The government also controlled the extent of exports and the contents of the sector's imports through a complex system of taxation and subsidies. Spinning firms were also subject to a mandatory 'hank yarn obligation' to ensure low-cost supply of specialized yarn for small 
handloom and power-loom firms. These arrangements oriented the mill sector (spinning and yarn) powerfully towards the small-scale power-loom based weaving sector, which in turn was oriented primarily towards domestic consumption. As Table 2 shows, nearly $99 \%$ of India's fabric production is in the power-loom sector, and even as late as 1990, exports constituted only $3 \%$ of total sales among the top-ten cohort of textile firms (Prowess data base2005).

Table 2: Structure of the Indian Textile Industry

\begin{tabular}{|c|c|c|c|c|c|c|c|}
\hline & $\begin{array}{c}1997- \\
98\end{array}$ & $\begin{array}{c}\text { 1998- } \\
99\end{array}$ & $\begin{array}{l}1999- \\
2000\end{array}$ & $\begin{array}{c}2000- \\
01\end{array}$ & $\begin{array}{c}2001- \\
02\end{array}$ & $\begin{array}{c}2002- \\
03\end{array}$ & $\begin{array}{c}\% \\
\text { Change } \\
-1997 / 8 \\
-2002 / 3 \\
\end{array}$ \\
\hline Spinning mills -- Large and medium (inc composite) & 1782 & 1824 & 1850 & 1846 & 1860 & 1875 & $5 \%$ \\
\hline Small scale spinning mills & 801 & 901 & 921 & 996 & 1046 & 1146 & $43 \%$ \\
\hline Spinning mills (Total) & 2583 & 2725 & 2771 & 2842 & 2906 & 3021 & $17 \%$ \\
\hline Large and med. Mills as $\%$ of Total & $58 \%$ & $57 \%$ & $56 \%$ & $59 \%$ & $54 \%$ & $53 \%$ & \\
\hline Small scale mills as $\%$ of Total & $31 \%$ & $33 \%$ & $33 \%$ & $35 \%$ & $36 \%$ & $38 \%$ & \\
\hline Weaving mills (Total) & 35287 & 35999 & 36902 & 37603 & 37707 & 38209 & $8 \%$ \\
\hline Large and medium weaving units & 187 & 199 & 202 & 203 & 207 & 209 & $12 \%$ \\
\hline Powerloom weaving units (small scale) & 35100 & 35800 & 36700 & 37400 & 37500 & 38000 & $8 \%$ \\
\hline Share of large weaving mills in Total & $1 \%$ & $1 \%$ & $1 \%$ & $1 \%$ & $1 \%$ & $1 \%$ & \\
\hline
\end{tabular}

Source: Ministry of Textiles, 2005

This strong domestic focus is illustrated by the export trajectory of Indian textiles. In the mid-1960s, well before India began to export apparel, it was already the eighth largest exporter of textiles in the world (UN Statistics 2005). With over half a billion dollars (\$591 million) of textile exports India had a 7.3\% share in the global market in 1965, just ahead of the US (with 6.6\%) and well ahead of Hong Kong at $11^{\text {th }}$ place with a $2 \%$ market share. Over the next twenty years - by the early 1980s - this picture had essentially reversed. India slipped to $14^{\text {th }}$ place in textile exports (just behind Turkey), while Hong Kong surged to $3^{\text {rd }}$ place. Later, by 1995 China had emerged as the largest textile and apparel exporter in the world and together with Hong Kong and South Korea, China accounted for nearly $31 \%$ of all textile and apparel sales globally by the late 1990s. Meanwhile, India's share in textile exports stagnated between 1.5 and $2.5 \%$ for most of the 1970 s and 1980 s, before rising to $3.8 \%$ in 2003 , still only a third of what it was in the 1960s. While East Asia emerged as the world's leading hub of apparel and textile 
exports, India went the opposite way. It turned strongly toward the domestic market and virtually withdrew from exports for the next two decades till the mid-1980s.

\subsection{Policy turnaround: deregulation and external sector reforms}

Things began to change after 1985 when the government revised its textile policies to shore up the sector's international competitiveness and increase the sector's foreign exchange earnings. After a late start and stagnant growth for several years, India's apparel and textile exports have recently grown at a rapid pace, especially in the last eighteen years. From barely \$30 million in 1970, India's apparel exports rose to nearly a billion dollars in 1990 and to $\$ 6.6$ billion in 2003 - increasing over 220 times in 33 years. Textile exports grew seven fold in 23 years - from \$1 billion in 1980 to $\$ 6.8$ billion in 2003. Taken together, India's apparel and textile exports accounted for $21 \%$ of merchandise exports in 2003, up from 3.8\% in 1970 (Ministry of Textiles 2005).

\subsubsection{Structural break in the mid-1980s}

Many in the literature associate this recent growth of apparel and textile exports with the opening up of India's economy to freer trade in 1991 (McKinsey 2001, D’Souza n.d.). But as Figure 3 shows, and as De Long (2003), Rodrik and Subramanian (2004) and Virmani (2004) have documented for Indian manufacturing as a whole, India's textile exports, and especially its apparel exports, took off in 1985, well before India liberalized trade in the early 1990s (see also Gangopadhyay and Krishnen 2005). ${ }^{14} 1985$ 86 represents something of a structural break in the export trajectory of Indian apparel (see Figure 3). After relatively slow growth in the late 1970s and early 1980s (compound annual growth rate of $1.4 \%$ per year in the first half of the 1980s), apparel exports surged at an annual compound rate of more than $19 \%$ between 1985 and 1990 - just prior to the introduction of external sector reforms in India in 1991. After liberalization the growth has continued, but at a slightly slower pace.

\footnotetext{
${ }^{14}$ DeLong 2003, Rodrik and Subramanian 2004, and Virmani 2004 all offer broader evidence that India's growth began in the mid-1980s rather than after liberalization was formally launched in 1991.
} 
Figure 3: Growth of India's textile and apparel exports showing structural break in 1985-86

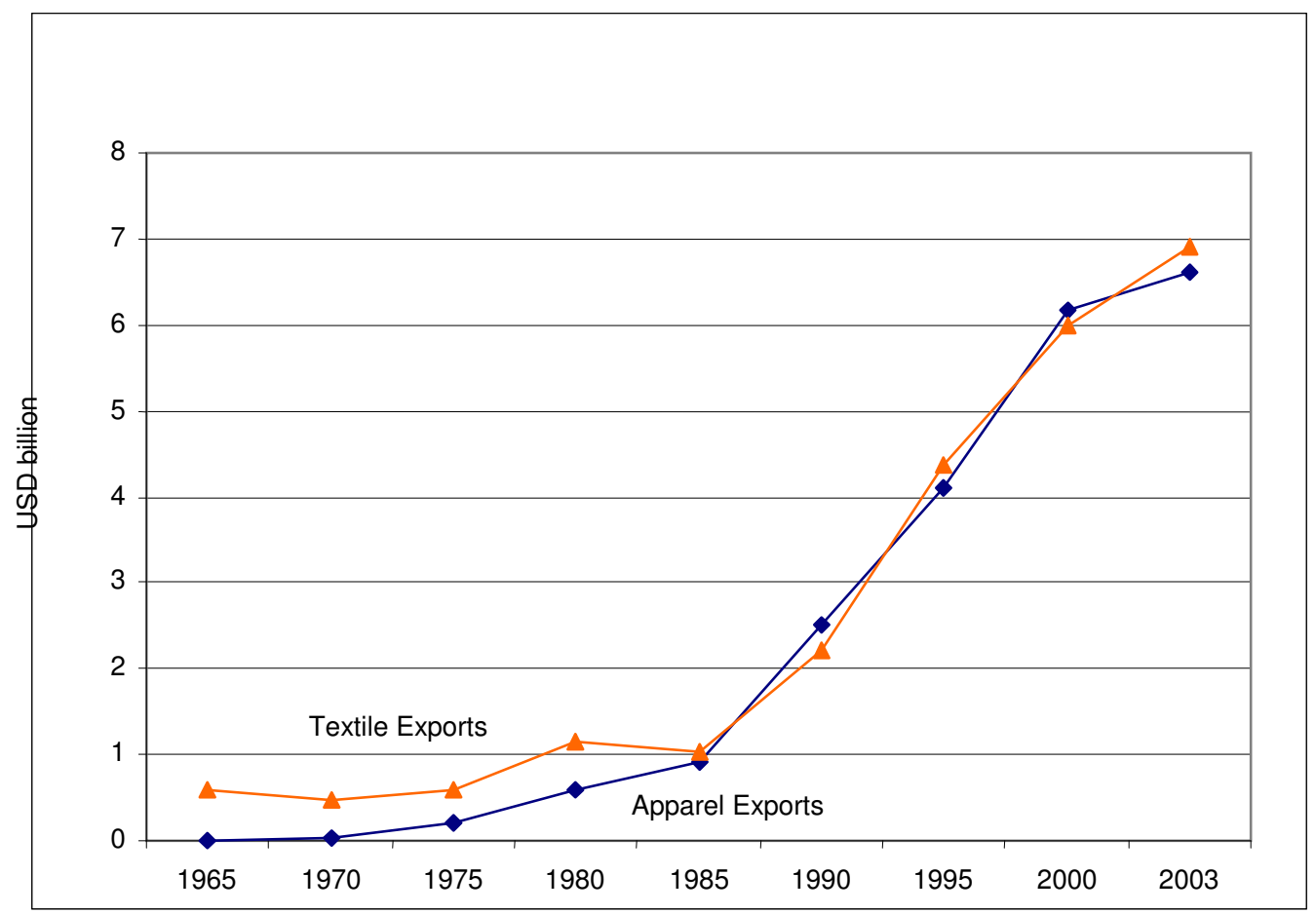

Source: Computed from UN Trade Statistics and data from Chatterjee and Mohan 1993

Indeed, as Table 3 shows, this shift in the pace of apparel exports occurred in three phases, each with distinct institutional and policy triggers. The first phase of growth took place in the early 1970s. Between 1970 and 1976 India's apparel exports grew seven-fold in six years_-rising from \$30 million to \$200 million, and growing from $3.8 \%$ of India's merchandise exports in 1970 to 11 percent in 1976. India's global share in apparel also doubled from 0.6 percent in 1970 to $1.5 \%$ in 1976 during this period (UN Statistics, 2005). As Chatterjee and Mohan (1993) have pointed out, this early growth was fuelled by a surge in demand from the US and Europe for Indian handloom garments, and clothing of indigenous cotton fabrics (see also Joshi 2003). But after a swift start, this first export surge waned in the late 1970s and early 1980s in part because of changes in consumer demand in the US and EU, but also because handloom exports, which were previously exempt from the purview of quotas under the Multifibre Arrangement that had come into existence in 1974, became subject to greater export restraints in the US and EU markets after 1977 (Chatterjee and Mohan 1993). 


\subsubsection{Domestic deregulation as the critical turning point}

The second phase of growth began in the mid-to-late-1980s (See Figure 3) and was triggered by the deregulation of the textile industry. Apparel exports grew strongly throughout the 1980s, doing particularly well after 1985 when the government, at the recommendation of the Verma Committee's 1985 report on textiles, adopted a new textile policy. Apparel exports more than doubled in just five years following the adoption of the new policy-rising from $\$ 914$ million in 1985 to $\$ 2.5$ billion in 1990 , an annual compound growth rate of more than $19.3 \%$ per year-an impressive resurgence by any standards. Under the Textile Policy of 1985 the government deregulated the hitherto heavily controlled textile industry, allowing firms to diversify their fabric and fibre base, raising the maximum limits on allowable investment, especially for small and medium firms, promoting exports through a variety of duty-draw back programs and encouraging the sector's technical modernization through the disbursement of cheaper lines of credit and specifically vested funds (such as in the TUF program) that allowed firms, especially exporters to import capital goods and technology at near world prices (Ministry of Textiles 1999). These domestic policy shifts, aimed as they were, at boosting the international competitiveness of the Indian textile and clothing sector, appear to have strongly influenced exports (see Gangopadhyay and Krishnan 2005 for a detailed account of the "pro-incumbent" policy mechanisms during this phase of growth and how they impacted the industry). ${ }^{15}$

After liberalization, the government further de-licensed the industry, initiated a progressive de-reservation of the sector (especially apparel), removed export barriers, and slashed import duties especially for exporters. During this third phase of growth, between the 1990s and early 2000s, textile and apparel exports grew robustly, but at a relatively slower pace compared to the 1980s (though from a higher base). Apparel exports grew at a CAGR of $8 \%$ per year between 1991 and 1995, and at $6 \%$ per year after the Asian currency crisis of 1997 , relative to $10 \%$ per year throughout the 1980 s. By

\footnotetext{
15 These reforms included: broad-banding of licenses, removal of restrictions on business houses if they operated in backward areas or if they were $100 \%$ export oriented, increase in maximum assets of small firms, duty free import of technology for export oriented firms or when it significantly improved costs.
} 
2003, apparel exports had increased more than seven times from $\$ 914$ million in 1985 , when apparel exports first took off, to $\$ 6.6$ billion in 2003 . Taken together with textiles, India's apparel and textile exports doubled between 1990 and 1996 (from $\$ 4.7$ billion to $\$ 9.2$ billion), and rose nearly three times to $\$ 13.5$ billion between 1990 and 2003 . Given India's late start, and the low level from which it began its apparel exports in the 1980s, this growth has been quite remarkable.

Table 3: Indian Apparel - Disaggregated Growth Trends

(Percent and US\$ millions)

\begin{tabular}{cc}
\hline Year & $\begin{array}{c}\text { Compound Annual Growth } \\
\text { Rate }\end{array}$ \\
\hline $1980-1990$ & 10.1 \\
$1991-2000$ & 6.8 \\
& \\
$1980-1984$ & 1.4 \\
$1985-1990$ & 19.3 \\
$1991-1995$ & 7.8 \\
$1996-2000$ & 5.9 \\
$2001-2003$ & 5.2 \\
\hline
\end{tabular}

Source: Calculated from UN Statistics and Table 4 Chatterjee and Mohan 1993

Trade value in current US\$ (million) deflated by CPI index base 1995 (Source WDI)

\subsection{Dominance of domestic capital in textile and apparel exports}

Several points can be made about this growth and turnaround. First, it was based on the domestic presence of a vast fibre and textile base, mainly of cotton, which influenced the composition and direction of India's early apparel exports. As we saw, the first export boom was fuelled by demand for indigenous fabrics and handloom garments.

\subsubsection{Growth with very little FDI}

Second, this growth was achieved with very little FDI. Unlike the importance of foreign direct investment in countries that have experienced some of the fastest export growth in apparel and textiles in recent years, there is very little FDI in India's recent export growth. Between 1991 and 2004 the Indian textile and apparel industry had received only $\$ 351$ million in cumulative FDI, or $1 \%$ of the total FDI inflows into India 
(of $\$ 32$ billion) during that period. ${ }^{16}$ By contrast, foreign-invested firms account for a third of all of China's apparel exports (UNCTAD 2005); Bangladesh's apparel industry received over 27\% of the country's total FDI (Bangladesh Board of Investment, 2005), and as is well documented, South Korean joint ventures played a critical role in the rise of Bangladesh's apparel exports in the 1980s (Rhee 1990). Similarly, Sri Lanka has an estimated one thousand garment export firms from 55 countries according to a SAARC study (SAARC 2005 n.d.). Of these, nearly 50\% are Board of Investment (BOI) approved ventures, and account for $90 \%$ of Sri Lanka's total garment exports (SAARC 2005, n.d.). Unlike these and other countries such as Mauritius, Mexico and the Caribbean basin nations, which similarly have a significant presence of foreign-invested capital in apparel and textile exports, India's textile and apparel exports are dominated by domestic firms as

Table 4 shows.

Table 4: India's Leading Textile and Apparel Companies (2004) - Ranked by Market Capitalization*

\begin{tabular}{|c|c|c|c|c|c|c|c|}
\hline $\begin{array}{l}\text { Sector } \\
\text { Rank }\end{array}$ & Company & Location & $\begin{array}{l}\text { Market } \\
\text { Cap } \\
\text { (US\$ } \\
\text { Million)** }\end{array}$ & $\begin{array}{l}\text { Net Sales } \\
\text { (December } \\
\text { 2004, US\$ } \\
\text { Million) }\end{array}$ & $\begin{array}{l}\text { Export } \\
\text { Earnings } \\
\text { (US\$ } \\
\text { Million) }\end{array}$ & $\begin{array}{l}\text { Exports } \\
\text { as a \% of } \\
\text { Turnover }\end{array}$ & $\begin{array}{l}\text { Operating } \\
\text { Profit } \\
\text { Margin }\end{array}$ \\
\hline 1 & $\begin{array}{l}\text { Arvind Mills } \\
\text { Indian Rayon \& }\end{array}$ & $\begin{array}{l}\text { Ahmedabad, Bangalore } \\
\text { Bangalore, Mumbai, West }\end{array}$ & 362.3 & 327.6 & 124.7 & $40 \%$ & $25 \%$ \\
\hline 2 & Industries & $\begin{array}{l}\text { Bengal } \\
\text { Thane, Mumbai, }\end{array}$ & 347.0 & 359.4 & 86.5 & $24 \%$ & $16 \%$ \\
\hline 3 & $\begin{array}{l}\text { Raymond } \\
\text { Indo Rama Synthetics }\end{array}$ & Bangalore & 331.3 & 233.8 & 48.9 & $21 \%$ & $12 \%$ \\
\hline 4 & (India) & MP, Delhi & 193.4 & 379.9 & 86.8 & $23 \%$ & $23 \%$ \\
\hline 5 & $\begin{array}{l}\text { Himatsingka Seide } \\
\text { Bombay Dyeing \& }\end{array}$ & Bangalore & 160.5 & 31.6 & 28.5 & $90 \%$ & $41 \%$ \\
\hline 6 & Mfg Co. & Mumbai & 153.2 & 207.6 & 14.18 & $7 \%$ & $5 \%$ \\
\hline 7 & $\begin{array}{l}\text { Alok Industries } \\
\text { Mahavir Spinning }\end{array}$ & Mumbai & 137.4 & 244.1 & 21.12 & $9 \%$ & $18 \%$ \\
\hline 8 & Mills & Ludhiana & 137.0 & 246.8 & 63.9 & $26 \%$ & $15 \%$ \\
\hline 9 & Welspun India & Gujarat, Mumbai & 135.6 & 83.7 & 62.2 & $74 \%$ & $20 \%$ \\
\hline 10 & Abhishek Industries & Ludhiana & 98.4 & 117.4 & 47.5 & $40 \%$ & $22 \%$ \\
\hline
\end{tabular}

Source:ETIG Database cf. "Textiles, Bright Prospects" in The ET500, December 2004, pp. 70, www.economictimes.com ${ }^{*}$ Ranked by the Economic Times for its ET500 database of the top 500 Indian companies

${ }^{* *}$ All conversions calculated on the basis of US $\$ 1=$ Rs. 43.8 as on February 11, 2005.b

Source : PROWESS (cmie)

Definition: 1) Export as a \% of Turnover = Export/Net Sales

${ }^{16}$ Similarly other sectors within India have received far more FDI that the Indian apparel and textile industry - the Indian auto-industry received 9\% of India's total FDI (more than $\$ 2.9$ billion), and the electrical equipment sector received $12 \%$ in the same period that the textile industry received $1 \%$ (Ministry of Industrial Policy and Promotion, 2005). 


\subsubsection{Exports preceded entry of global buyers}

Second, although Indian apparel exports are channeled through many foreign buyers today, few of the largest global players or their clothing chains were present in India in any significant way when Indian apparel exports first took off in the mid-1980s. Unlike the key role that large buyers, major department stores and global retailers like Wal Mart, Sears, Nike, Liz Claiborne, VF and others have played in organizing the East Asian, Bangladeshi, Sri Lankan, and Latin American, apparel export market India's export upsurge in the mid-1980s was driven primarily by small-volume, direct exports from medium sized Indian producers to retailers, wholesalers, and medium sized buyers initially in the EU, and subsequently in the US. Though today the biggest names in apparel are sourcing directly from India (e.g, Gap, Banana Republic, Ann Taylor, Nike, Reebok, Liz Claiborne, Tommy Hilfiger, Abercombie and Fitch, Sears, Sara Lee) it is striking that till the late 1990s, and early 2000s few global buyers had a significant direct presence in India-Wal Mart and Target did not have their own offices in India till as late as 2004/5; most buyers sourced from India indirectly through local buying houses and other intermediaries. That few of the largest global buyers played any direct role in building deep sourcing networks among Indian producers at the start of India's export surge in the mid-1980s is in contrast to the central role that such buyers or third country producers (such as South Korean producers in Bangladesh) historically played in initiating and channeling apparel exports from several supplier countries (Rhee 1990, Gibbon 1999, Bair and Gereffi 2002).

\subsubsection{Integration without Regional Trade Agreements}

A third factor that has driven apparel exports in many supplier countries, namely, the incorporation of the supplier nation into major regional or preferential trade agreements with their main buyer countries-- such as NAFTA, CBI, EU enlargement, AGOA, is also absent in India's case. India's recent export growth has occurred despite its absence from every major regional free trade agreement (RTA). Table 5 shows a striking pattern. In the last decade, the fastest growing apparel exporters among the top 15 exporting countries have been five: Mexico, Romania, Bangladesh, Turkey and of course, China. Apart from China, which received massive FDI from Hong Kong, Taiwan 
and Japan throughout the 1980s, and which along with Hong Kong had already emerged as a leading exporter of apparel in the late 1980s and the top exporter after 1995, the other four are part of a major RTA, customs union, or bilateral trade agreement. In each case the supplier country experienced rapid surges in the 1990s, after becoming part of its respective hemispheric free trade agreement -- NAFTA in 1994 in the case of Mexico, EU enlargement in the case of Romania, EU customs union in case of Turkey, and least developed country status and tariff-free entry for Bangladesh into Europe). Thus, as Table 5 shows, Mexico, whose apparel exports grew at an impressive annual average growth rate of $17.5 \%$ between 1993 and 2003, increased its market share from barely 0.5\% in 1990 to $0.9 \%$ in 1993 to 3.2\% in 2003. On average Mexico added \$597 million per year to its apparel export value every year between 1993 and 2003 (see Table 5); Romania's apparel exports grew at an annual average rate of 14\% between 1993 and 2003, and its global share rose from $0.3 \%$ in 1990 to $0.5 \%$ in 1993 to $1.8 \%$ of the world market in 2003; Bangladesh grew at 11\% annually between 1993 and 2003, and increased its share from $0.6 \%$ in 1990 to $1 \%$ in 1993 and nearly $2 \%$ in 2003 . Turkey similarly increased its market share from $3.1 \%$ to $4.4 \%$ between 1990 and 2003. India's annual average growth of 5\% during this period, on par with Turkey's, without the benefit of FDI or the deep organizing role of global buyers, or participation in a trade-enhancing RTA is thus impressive. 
Table 5: Growth Rates of the top 15 Apparel Exporters between 1993 and 2003

(US\$ million and percentage)

\begin{tabular}{lccccc}
\hline \multicolumn{1}{c}{ Country } & $\begin{array}{c}\text { Trend Growth } \\
\text { Rate (US\$ } \\
\text { million) }\end{array}$ & $\begin{array}{c}\text { Average Annual } \\
\text { Growth Rate } \\
\text { (percent) }\end{array}$ & $\begin{array}{c}\text { Global } \\
\text { Share } \\
\text { 1993 (\%) }\end{array}$ & $\begin{array}{c}\text { Global } \\
\text { Share } \\
\text { 2003 (\%) }\end{array}$ & $\begin{array}{c}\text { Change } \\
\text { in Share } \\
\text { (\% pts) }\end{array}$ \\
\hline China & 1780.5 & 6.27 & 14 & 23 & 9 \\
China, Hong Kong SAR & -286.2 & -1.38 & 15.9 & 10.2 & -5.7 \\
Italy & -59.0 & -0.41 & 8.5 & 7.4 & -1.1 \\
Turkey & 228.0 & 3.83 & 3 & 4.4 & 1.4 \\
Germany & -6.9 & -0.16 & 5 & 4.3 & -0.7 \\
Mexico & 597.2 & 17.51 & 0.9 & 3.2 & 2.3 \\
France & 8.1 & 0.12 & 3.5 & 3.1 & -0.4 \\
India & 201.7 & 4.76 & 2.3 & 2.9 & 0.6 \\
USA & -69.7 & -1.28 & 3.8 & 2.4 & -1.4 \\
Belgium & 194.7 & 5.01 & & 2.4 & -0.4 \\
United Kingdom & -90.6 & -2.33 & 2.4 & 2 & -0.4 \\
Indonesia & 22.4 & 0.63 & 2.7 & 1.8 & -0.9 \\
Romania & 225.5 & 14.02 & 0.5 & 1.8 & 1.3 \\
Rep. of Korea & -271.2 & -5.85 & 4.7 & 1.6 & -3.1 \\
Bangladesh & 250.3 & 10.73 & 1 & 1.6 & 0.6 \\
\hline
\end{tabular}

Source: Computed from UN Trade Statistics

Note 1) Belgium growth rates are for 1999-2003

2) All values deflated by CPI index (US $\$$ ) base year $=1995$

\subsubsection{The rise of a tier of globally competitive domestic firms}

The final point is that this recent growth does not fit very well with standard neoliberal narratives of export growth being unleashed by the liberalization of the economy in the early 1990s. As we saw, the turnaround in apparel and textile exports was triggered by the deregulation of the industry in 1985 and a progressive revision of the state's textile policy (in 1985, 1988, 1990, 2000 and 2003), rather than by the liberalization of trade in the early 1990s. The new textile policy of 1985 was a turning point in spurring apparel export growth, and helped transform the capabilities of a whole tier of firms. The process of de-regulation that this revised policy initiated, worked in three specific ways. (a) It induced cycles of investment and technical upgrading in the sector, (b) very specifically promoted exports and (c) diversified the sector's fibre base. The government raised the upward limit on investment allowed to small and medium firms, ancillary units, and those investing in lagging regions. Exporters had an even freer hand-they could set up units of 
any scale at any location, and import duty-free machinery and equipment (see Gangopadhyay and Krishnan 2005 for a detailed list of policy changes). The government used generous subsidies, duty-drawback programs to encourage firms to establish export oriented units, and absorb new technology. The increased investment thus took two forms - capacity increases and investments in technical modernization. Between 1990 and 2003 the average investment per firm in plant and equipment in the top-ten cohort of textile firms increased 43 percent in real terms (constant 1995 dollars). In the apparel sector -which was reserved for small scale firms till 2003 - mean investment per firm in plant and equipment increased an impressive 315\% from \$1.2 million in 1995 to $\$ 5.1$ million in 2003 (in constant 1995 dollars). ${ }^{17}$ Two additional measures of the rising capital intensity and investment in plant, equipment and technology are illustrated in figures 4 and 5. At the industry level, the capital labor ratio of textile and apparel firms as a whole trended upwards throughout the late 1980s and 1990 (Figure 4); ${ }^{18}$ Similarly, at the firm level, investments in plant and equipment (as a percentage of sales) as well as gross fixed assets (as a percentage of sales) increased sharply in the 1990s (see Figure 5). ${ }^{19}$ The average scale of firms in the textile and apparel industry thus began to increase in the late 1980s and 1990s.

\footnotetext{
${ }^{17}$ Indeed, one of the policy changes in 1985 and again in 1991 as noted in note 14, was to raise the upward limit on investment allowed to small firms.

${ }^{18}$ These figures are computed using Annual Survey of Industries data. Capital employed is deflated using a weighted price series for capital constructed for the textile sector by Danish Hashim. See Hashim 2005)

19 These are calculation for a sample of 77 textile and apparel firms for which full panel data is available from CMIE's Prowess database.
} 
Figure 4: Capital labor ratio - Indian Textile industry 1974-1998

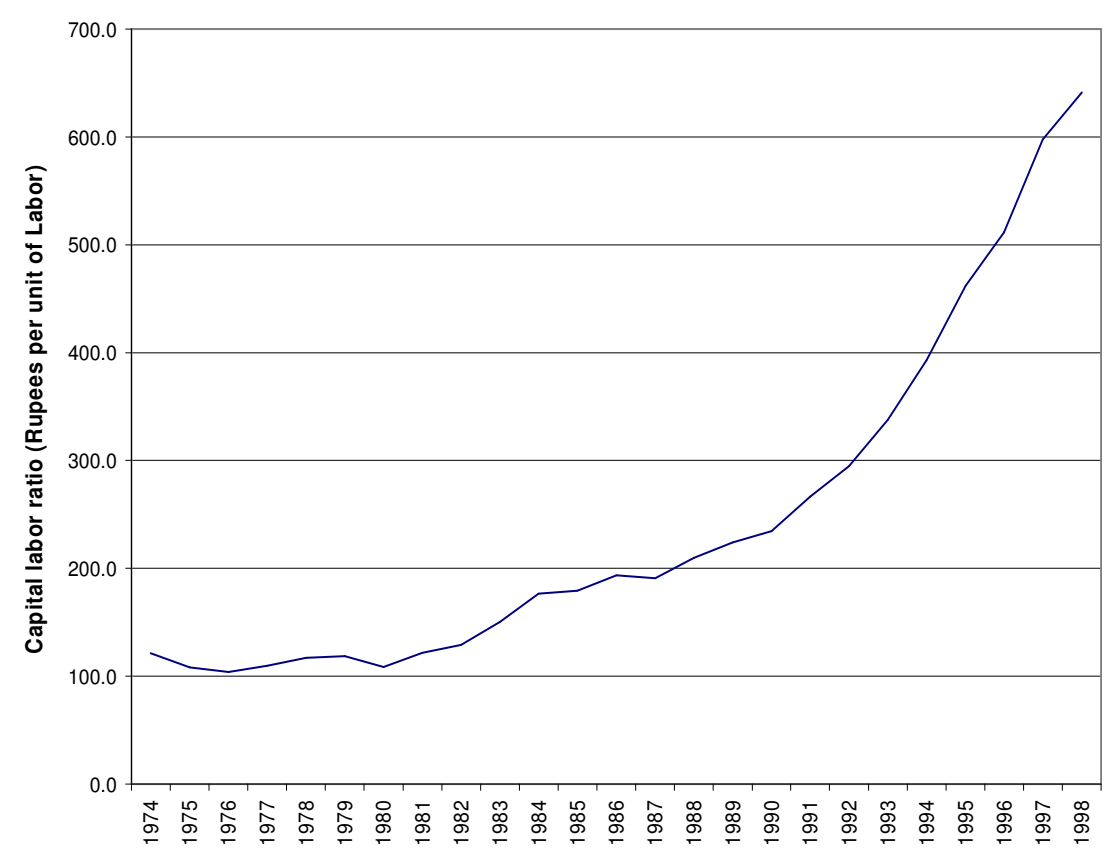

Source: ASI data, capital employed deflated using a weighted price series for capital constructed by Hashim (2005)

Figure 5: Ratio of plant and machinery to sales in a sample of 77 textile and apparel firms 1989-2003

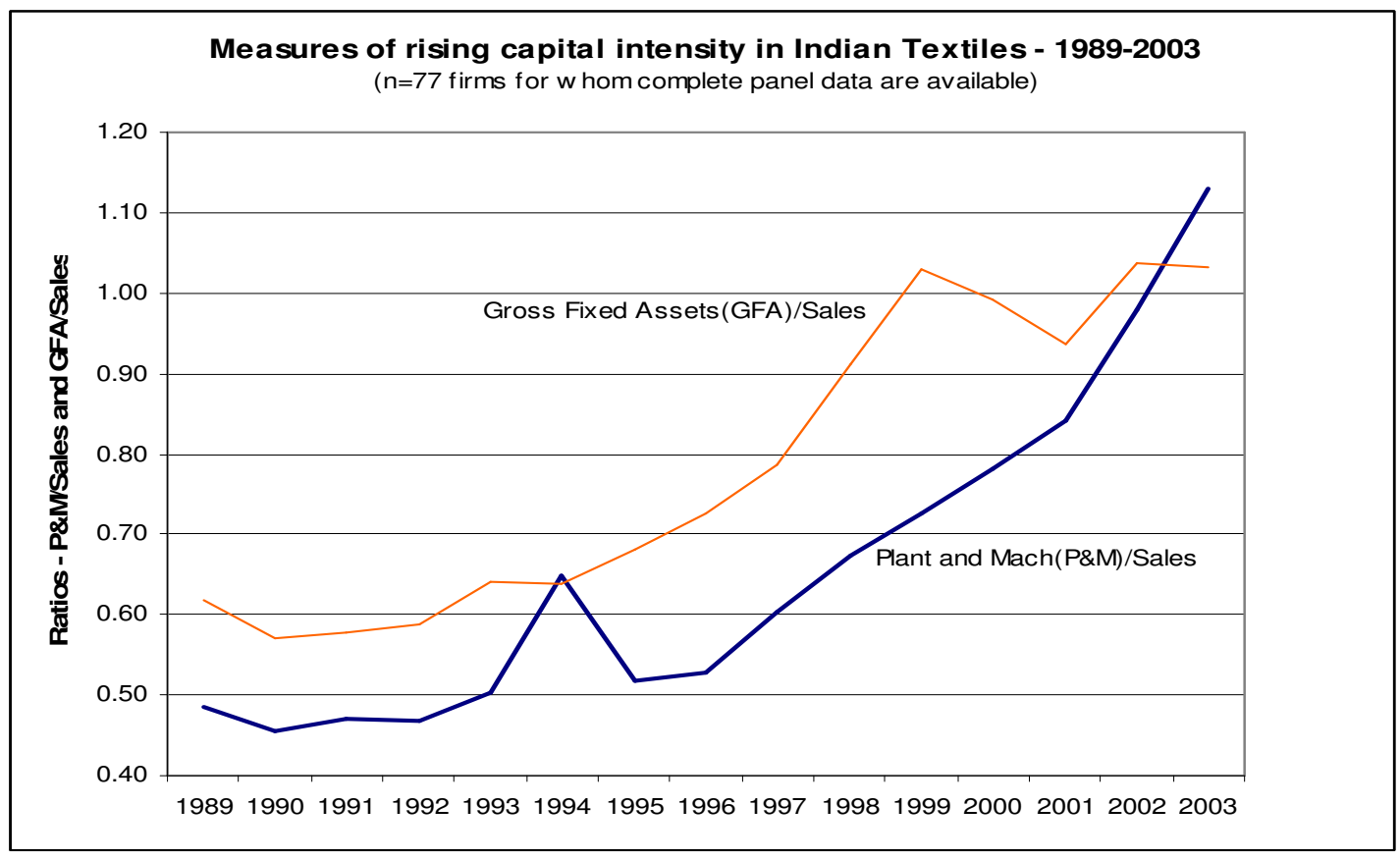

Source: CMIE, Prowess database 
These investments and cycles of technical upgrading helped transform the capacities of a whole subset of firms, and with the government's generous export incentive exports grew sharply. For example, Arvind Mills, the second largest textile and apparel company in the country increased its exports from 12 percent of sales in 1990 to 42 percent of sales in 2003 (or from \$15 million to \$111 million in 1995 constant dollars). Similarly, Raymond Ltd, the third largest textile and apparel group in India, increased exports from $5 \%$ of sales in 1990 to $17 \%$ of sales in $2003 .{ }^{20}$ Overall, the average share of exports (as a percent of total sales) in the top-ten cohort of top ten apparel firms has grown to more than $53 \%$ today, and in the case of the much more domestically oriented textiles sector, exports rose by 12 percentage points from 3 percent of sales in 1990 to over 15 percent in 2003 (calculated from CMIE's Prowess database).

Similarly, the reforms of 1985 also helped diversify the sector's fibre base. This diversification is reflected in changing patterns of consumption at home as well in the composition of India's exports. For example, the consumption of cotton yarn and fabric within India fell from $76 \%$ in 1985-86 to about $66 \%$ in 1999 and to just over $50 \%$ in 2003 (Ministry of Textiles 1999, Ministry of Textiles 2005). Though cotton-based fabric and garments still constitute $61 \%$ of India's textile and apparel exports, the share of MMFbased yarn, fabric and garments in total exports have steadily increased from $14 \%$ in 1990 to $19 \%$ in 2003 (See Figure 6). Moreover, by 2003, nine of India's ten largest textile firms listed synthetic, man-made or blended fabrics as their primary economic activity (Prowess database 2005). The government's 1985 Textile Policy thus had an important transformative impact, even though India's emerging MMF market is still only a fourth of China's (the top producer globally) and half of USA's (the second largest producer), it has grown significantly in the last two decades (Ministry of Textiles 2000, Compendium of Textile Statistics, Ministry of Textiles 2005).

\footnotetext{
${ }^{20}$ Calculated from CMIE's Prowess database.
} 
Figure 6: Decomposition of product segment shares in India's textile and apparel exports 1992-2003

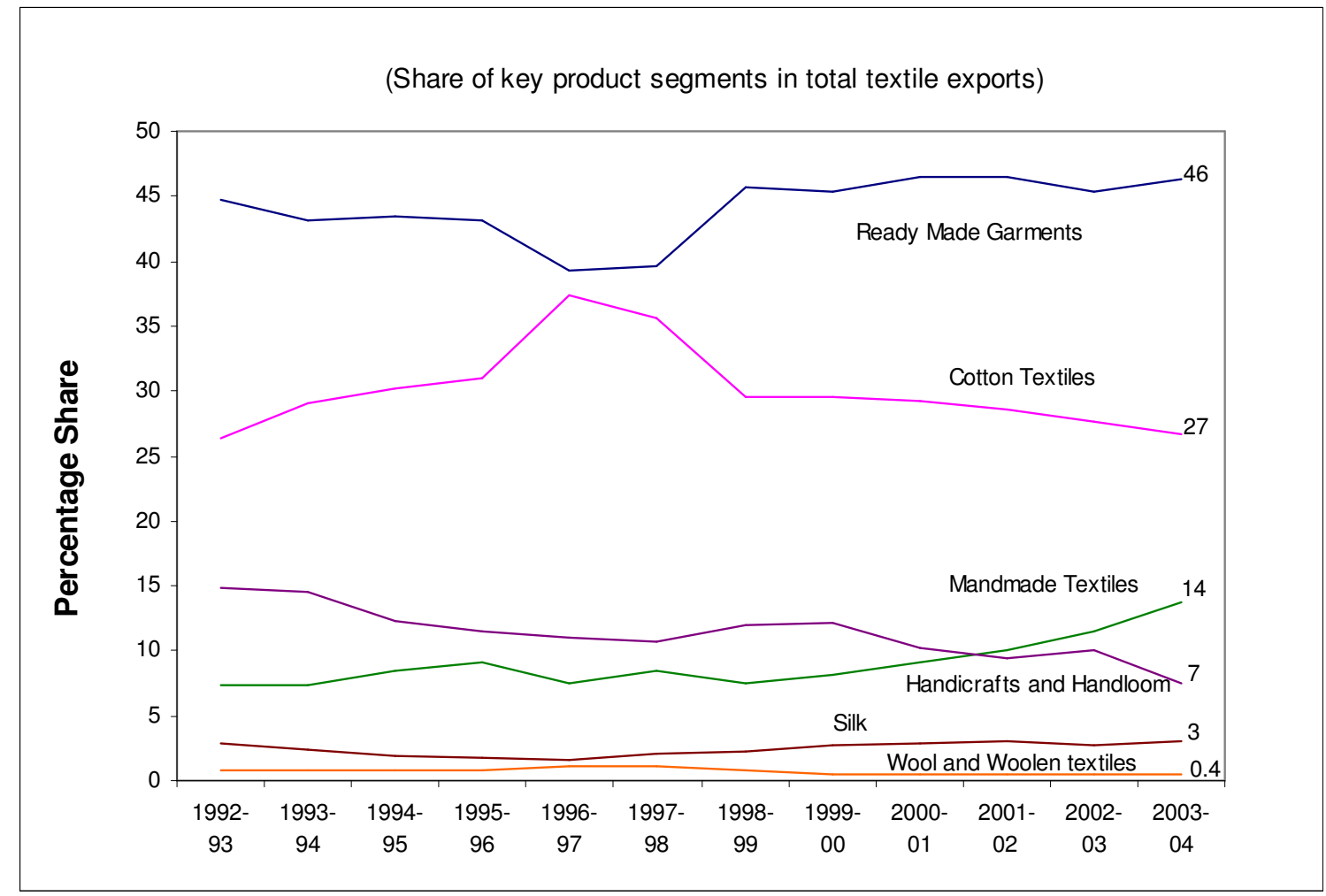

Source: Ministry of Textiles

\subsubsection{Summary}

In sum, then, this section made two points. First, that the domestic reforms of the mid-1980s were critical in triggering growth in the apparel and textile sector. Their initial focus on investment and technical upgrading in the textile and apparel sector created a tier of strong domestic firms in the spinning and apparel sector that increased investment, modernized their technical base, diversified their product mix and over time emerged as leading exporters. Trade liberalization of the 1990s deepened the processes that had the process of deregulation had already begun in 1985 .

Second, we also saw in this section that the early phase of export growth in India's textile and apparel industry was different in important ways from the experience of other countries that have emerged as major apparel exporters recently. In contrast to 
some of its closest competitors, India's recent export growth was achieved with relatively little FDI, without a major role of foreign buyers in deeply organizing Indian supply networks, and without the trade-channeling effect of participation in any major regional trade agreements. These data can be read in two ways. First, that India's export growth, though more rapid in the recent past, merely tracked rising global growth in apparel exports during this period (see Ramaswamy and Gereffi 1998), and that with greater FDI, a deeper insertion of Indian suppliers into major global buyer networks, and participation in RTA's, India's growth would have been much faster.

While this may well be the case, as many have argued in the literature (McKinsey 2001, for example), a second reading of the data, and which I argue for in this paper, is that regardless of the debate over the ills or benefits of the government's autarkic turn in the late 1960s and 1970s, the same factors that have contributed to the slow global integration of the Indian textile and apparel sector, are also generating unexpected opportunities for the industry to upgrade itself and cultivate new sources of competitive advantage that, if nurtured well, have the potential to move it along a higher value-added and more diversified growth path of adjustment and upgrading, along with scaling up.

\section{Legacies of import substitution}

There are many criticisms of India's protectionist phase during the 1960s through the 1980s. Critics argue the government's attempt to control and shape the textile and apparel industry resulted in high costs, technological obsolescence, uneconomical scales

of operation which shackled productivity and kept the textile and apparel industry tied to inefficient scales of production and technologies (McKinsey 2001, Hashim 2005, World Bank 2000).This protectionist period shaped key legacies.

There are four key legacies of this earlier period that are playing an important part in the transformation of the textile and apparel sector today. (1) A history of small batch production that was inadvertently reinforced by the government's licensing policies, its reservation policies and labor laws that kept the average apparel establishment small in scale; (2) generalist skills centered around the 'master tailor' - who served as master 
cutter and designer and innovator and around whom garment production was organized. (3) A large market size which helped anchor domestic firms across the sector's value chain-from the mill sector to apparel—and elicited the rise of a number of regional, national and sectoral support institutions including textile research agencies and export promotion councils.

(4) India's low labor costs and low wages, which were historically undercut by poor productivity. India is generally seen as one of the lowest cost apparel producers globally. A recent study estimated India's labor costs (total employment cost for labor across industries) to be amongst the lowest (2.024 Euro) in the world, a sixth of even China's (13.88 Euro) (Economic Times, 2005), but India's poor productivity has always undermined its labor cost advantage. Even in the early 1990s when Indian apparel exports were growing rapidly, India's productivity lagged behind most of the major exporters of apparel (Table 6 and

Table 7). Thus, even aside from the rigidities introduced by some of India's labor laws, low labor costs have never automatically added up to low production costs or low unit costs in Indian apparel. This mixed cost advantage pushed many better performing firms to look elsewhere for advantage in the export market, as we see next.

Table 6: Productivity Levels of Apparel Firms (Number of pieces per day), 1993

\begin{tabular}{|l|c|c|c|c|c|}
\hline & Ladies Blouses & Dresses & Skirts & Mens' Shirts & Men's Trousers \\
\hline Hong Kong & 20.56 & 20.17 & 19.25 & 20.87 & 19.25 \\
\hline Taiwan & 18.89 & 12.44 & 16.63 & 18.18 & 16.12 \\
\hline Thailand & 16.97 & 12.19 & 20.47 & 19.75 & 13.08 \\
\hline South Korea & 14.59 & 8.77 & 17.54 & 17.39 & 15.55 \\
\hline China & 10.93 & 7.83 & 13 & 13.96 & 6.71 \\
\hline India & 10.18 & 6.25 & 9.62 & 9.12 & 6.84 \\
\hline \multicolumn{7}{|l|}{ Source: S.R. Khanna, 1993, The Challenge of Global Competition in the 1990s. ICRII R Memo. } \\
\hline
\end{tabular}


Table 7: Comparative Labor Costs in the Apparel Industry, 2000

\begin{tabular}{lc}
\hline Country & Average hourly wage in US\$ \\
\hline United States & 11.2 \\
Germany & 10 \\
Hong Kong, China & 5.1 \\
Rep. Korea & 5.1 \\
Slovenia & 2.7 \\
Mexico & 1.8 \\
South Africa & 1.6 \\
Malaysia & 1.4 \\
El Salvador & 1.1 \\
Mauritius & 0.9 \\
Slovakia & 0.9 \\
China & 0.9 \\
India & 0.7 \\
Sri Lanka & 0.6 \\
Indonesia & 0.2 \\
Pakistan & 0.2 \\
Bangladesh & 0.2 \\
\hline
\end{tabular}

Source: ILO 2003, EU 2003, cf. UNCTAD 2005

\section{$5 \quad$ Emerging Firm Strategies}

Based on these histories, three major paths of global integration are discernable among Indian textile and clothing firms that have successfully inserted themselves in the export market in recent years.

\subsection{Flexible, small-batch production}

As we have seen, the state's licensing regime and labor policies historically pushed the Indian apparel industry toward small scales of operation and small runs rather than high turnover, low-margin volume production. These small scales of operation had three implications for how the sector developed. They forced firms to learn how to manage small-batch production and variability in orders, efficiently. At the same time, small capacities of Indian apparel firms oriented their exports toward the European market early on, rather than the US -- where orders were much larger, especially by 
discount retailers like Sears, Target and Walmart. On the one hand, this prevented the early Walmartization of the Indian textile and apparel industry, and on the other hand it created more stable, often learning and feedback intensive ties between the Indian suppliers and their European buyers. As the literature has documented, the links between Indian apparel exporters in the 1980s and 1990s tended to be with small and medium sized wholesalers and retailers or their buying agents, than with large chains. Most of these buyers themselves could not take the risk of placing large orders per style - most sought 2500 to 4000 pieces per order, rather than 100,000 pieces. At the same time they also sought flexibility and the ability on the part of their suppliers to handle fast-changing orders of variable designs and specifications (Vishal interview, 2005, Pacific Apparel Exports, Interview, 2005). Thus, a whole cohort of apparel exporters who came on board in the 1980s and 1990s bypassed the biggest clothing chains in Europe and the US, and instead developed relatively longer term, often feed-back intensive relational ties with their buyers (Tewari 1999). Over time, many exporters became progressively quite proficient at handling complex designs in small-runs, multiple product lines and volatility in orders cost-effectively. These traits are especially valuable in an environment where intense competition, uncertainty and fragmentation have characterized demand - as it has since the 1980s - and where customization, variability, good quality and low costs are no longer niche strategies, but are widely demanded by buyers.

When Indian suppliers diversified into the US market in the 1990s, who would one expect to be their major buyers? Not surprisingly, firms which themselves sought smaller runs of higher value products of variable designs have been the key buyers of Indian apparel in the US market. Buyers like Gap, Banana Republic, Liz Claiborne, Ann Taylor, Abercombie and Fitch and department stores such as Dillards, and JC Penny are some of the prominent US buyers of Indian apparel today, and began sourcing from India much earlier than mass-distributors and discount retailers like Wal Mart, K-Mart, Target and others who are only now intensifying their procurement from India. Indeed, in interviews conducted in three apparel hubs across the country between 2000 and 2005, Indian firms themselves routinely reported preferring to work with buyers who placed smaller orders than with bulk buyers like Wal Mart. Discount retailers like Wal Mart 
'offer too low margins," are too footloose and offer little room to learn and grow, many said. Few firms expressed a willingness to take the risk of making large investments in capacity increases to supply firms like Wal Mart for margins that were far too low to allow room for growth. Working with buyers who place smaller orders of variable designs has also led to an improvement in the unit value realization of Indian suppliers.

A central part of the competitive advantage of good performing firms that are supplying to higher value, relatively up-market specialty buyers such as Gap, Banana Republic, J. Crew, is their ability to contribute to design -- not only in preparing samples and prototypes, but in translating concepts into varieties of finished designs, as well as introducing designs of their own. Several firms have their own design departments and in the last five years have begun to work closely with overseas designers and/or agents. One knitwear firm that supplies to specialty stores in the UK and US reported how they had co-developed and produced a knit polo shirts for buyers like Firetrap and Diesel—of designs that required "100-160 different operations to implement." Manufactured at Rs. $\$ 22$ per T-shirt, these items were retailed at $\$ 80$ at key stores, including, Harrods (Eastman Interview Tirrupur, 2005). ${ }^{21}$ As the chairman of another leading textile and apparel company (Raymond's) put it in a recent interview, "China will be a large volume player [in textiles] while India will always be a higher quality lower volume player..." (Singhania in the Hindu, 2005). While it is important not to obscure China's lead in a range of high quality product segments and its superior productivity, this example in fact illustrates a broader trend toward higher value apparel exports by a growing subset of Indian firms and is reflected in the rising unit values of several products in India's export basket as we see the Figure 7 and Table 8. Figure $\mathbf{7}$ shows the recent evolution of India and China's (inflation adjusted) unit values of cotton trousers and shorts (for men and boys and women and girls) between 1995 and 2003. Table 8 summarizes broader data for India's unit values in six of its leading categories in apparel exports.

\footnotetext{
${ }^{21}$ See also Palpaceur (2004) who reported in a recent study on sourcing patterns of French retailers and how some who source from India reported having chosen their Indian supplier because of their design ability (Palpaceur, 2004).
} 
Figure 7: India and China's unit values (Inflation adjusted dollars per unit)

Men's/boys cotton trousers and shorts (woven) HS 620462

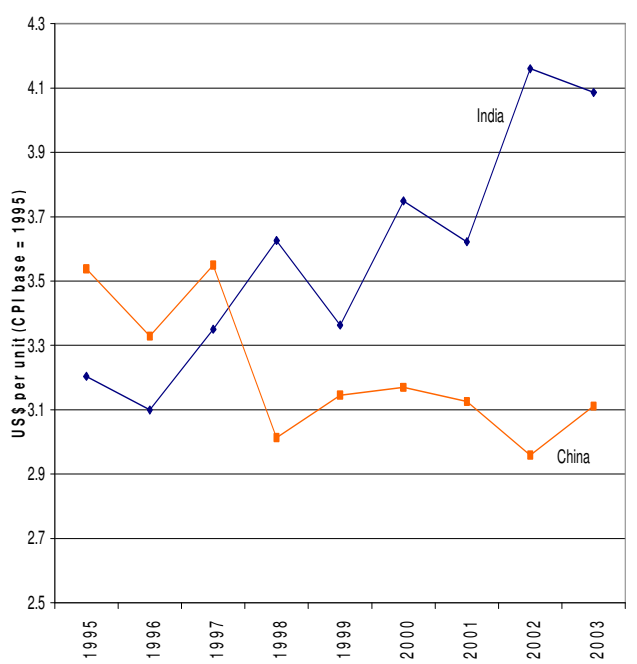

Women's/girls cotton trousers and shorts (woven)

HS 620342

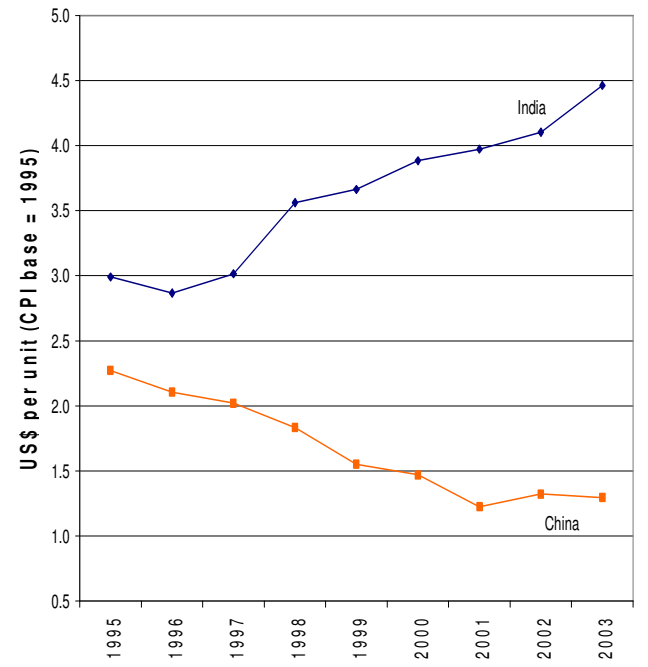

Table 8: Normalized Unit Values for India's Leading Apparel Exports to the World (CPI base = 1995)

(Constant \$/unit)

\begin{tabular}{|c|c|c|c|c|c|c|c|c|c|c|c|}
\hline $\begin{array}{l}\text { HS } \\
\text { Code }\end{array}$ & Product category & 1995 & 1996 & 1997 & 1998 & 1999 & 2000 & 2001 & 2002 & 2003 & Trend \\
\hline 610910 & $\begin{array}{l}\text { T-shirts, singlets of cotton, } \\
\text { knitted }\end{array}$ & 3.1 & 3.0 & 3.6 & 3.0 & 3.2 & 3.0 & 3.0 & 2.7 & 2.9 & -0.04 \\
\hline 620630 & $\begin{array}{l}\text { Womens/girls blouses, shirts, } \\
\text { cotton, woven }\end{array}$ & 4.2 & 4.1 & 3.9 & 3.8 & 3.7 & 3.4 & 3.4 & 3.5 & 3.5 & -0.10 \\
\hline 610510 & Mens/boys shirts, cotton, knitted & 3.3 & 1.1 & 4.0 & 3.8 & 4.0 & 3.8 & 3.7 & 3.6 & 3.4 & 0.12 \\
\hline 610610 & $\begin{array}{l}\text { Womens/girls blouses, shirts, } \\
\text { cotton, knitted }\end{array}$ & 3.1 & 3.1 & 3.4 & 3.0 & 3.0 & 2.5 & 2.4 & 2.5 & 2.5 & -0.11 \\
\hline 620342 & $\begin{array}{l}\text { Mens/boys trousers and shorts, } \\
\text { of cotton, woven }\end{array}$ & 3.0 & 2.9 & 3.0 & 3.6 & 3.7 & 3.9 & 4.0 & 4.1 & 4.5 & 0.20 \\
\hline 610831 & $\begin{array}{l}\text { Womens/girls nightdresses of } \\
\text { cotton, knitted }\end{array}$ & 2.5 & 2.4 & 3.0 & 2.7 & 2.8 & 2.7 & 2.7 & & 2.5 & \\
\hline 620462 & $\begin{array}{l}\text { Womens/girls trousers, shorts, of } \\
\text { cotton, woven }\end{array}$ & 3.2 & 3.1 & 3.3 & 3.6 & 3.4 & 3.7 & 3.6 & 4.2 & 4.1 & 0.12 \\
\hline & $\begin{array}{l}\text { Share of India's total apparel } \\
\text { exports }\end{array}$ & $62 \%$ & $64 \%$ & $61 \%$ & $59 \%$ & $53 \%$ & $53 \%$ & $57 \%$ & $57 \%$ & $56 \%$ & \\
\hline
\end{tabular}

Source: Calculated from Comtrade Data; CPI base $=1995$ 
As Table 8 shows, unit values of three of India's rapidly growing export items, mens/boys cotton trousers and shorts (non-knitted), women's cotton trousers and shorts (non-knitted) and mens/boys cotton knitted shirts - each registered increases over the last eight years. The unit value of mens/boys cotton trousers increased from $\$ 3.0$ per unit to \$4.5 per unit in real dollars (constant 1995) between 1995 and 2003, and women's cotton trousers/shorts and men's cotton knitted shirts each added 12 cents per year to their unit value between 1995 and 2003 (real 1995 dollars). Furthermore, Table 9 shows that the growth in trade value has continued after the removal of quotas-so far, at least in the US market (USITC Data 2005). ${ }^{22}$

Table 9: Post-MFA Growth of India's Apparel Exports to the US, January to May 2005 (Selected product categories)

\begin{tabular}{|c|c|c|c|c|c|}
\hline \multirow[b]{2}{*}{$\begin{array}{c}\text { SITC } \\
\text { Number }\end{array}$} & \multirow[b]{2}{*}{ Description } & 2004 & $\begin{array}{c}2004 \text { YTD } \\
\text { (Jan- } \\
\text { May) }\end{array}$ & $\begin{array}{c}2005 \text { YTD } \\
\text { (Jan- } \\
\text { May) }\end{array}$ & \multirow{2}{*}{$\begin{array}{c}\text { Percent } \\
\text { Change } \\
\text { YTD2004 } \\
- \\
\text { YTD2005 }\end{array}$} \\
\hline & & \multicolumn{3}{|c|}{ In 1,000 Dollars } & \\
\hline 8437 & $\begin{array}{l}\text { Men's/boys' shirts of knitted or } \\
\text { crocheted textile fabrics }\end{array}$ & 157,521 & 65,565 & 103,549 & $57.90 \%$ \\
\hline 8414 & $\begin{array}{l}\text { Men's/boys' trousers, shorts etc of } \\
\text { woven textile materials }\end{array}$ & 141,685 & 61,764 & 85,467 & $38.40 \%$ \\
\hline 8425 & $\begin{array}{l}\text { Women's/girls' skirts and divided } \\
\text { skirts of woven textile fabric }\end{array}$ & 132,716 & 70,390 & 178,017 & $152.90 \%$ \\
\hline 8426 & $\begin{array}{l}\text { Women's trousers, overalls, } \\
\text { breeches, shorts etc. of woven textile } \\
\text { fabrics }\end{array}$ & 114,833 & 60,449 & 68,039 & $12.60 \%$ \\
\hline 8454 & $\begin{array}{l}\text { T-shirts, singlets, tank-tops etc of } \\
\text { knitted or crocheted textile fabric }\end{array}$ & 51,611 & 21,514 & 41,680 & $93.70 \%$ \\
\hline All & All apparel export categories & $2,357,070$ & 984,291 & $1,362,117$ & $38.40 \%$ \\
\hline
\end{tabular}

Source: United States International Trade Commission

It is significant -- and surprising - to see the rapidity with which design has emerged as a source of competitive advantage in Indian apparel exports in recent years-

\footnotetext{
${ }^{22}$ USITC data are not measured in the HS system. Hence the discrepancy between the categories for which India's unit values are calculated (from UN data) in Table 8 and figures for India's exports to the US from the US International Trade Commission in Table 9.
} 
especially given the relatively 'young' export history of Indian apparel and the general image of low quality often associated with some Indian apparel exports. As one firm who is a major supplier for several European and US specialty stores such as Nike explained, "When items have complicated designs with complex patterns, many fabrics, a variety of colors -- you have to break them down. Many different operations and techniques are required, you have to figure them out" (Gokuldas Exports Interview 2005). When buyers have such items, many of them tend to come to India, this firm said, rather than going to Bangladesh or China. "A Chinese firm would probably refuse the order. In their system, the more complicated the design, the more complicated the line gets, and lower the efficiency. This complicates the bottom line. It is not worth their while" - especially if the volumes are small (Gokuldas Exports, Interview, 2005). Why, then, would an Indian firm be willing to take the order? Why are buyers like Nike and others turning to India for the production of items with complex designs - e.g., shorts and casual trousers with many pockets, different colors, designs with all sorts of complications; jackets using multiple fabrics and motifs?

The answer, in part has to do with an important legacy of the sector's industrial organization - the historically small average scales of operation in Indian apparel created the conditions for the preservation of generalist skills —of the master tailor-at the heart of the Indian apparel industry. These general purpose skills allow complexity to be handled cost-effectively and flexibly given that the rigidities of too narrow a division of labor are absent The firm mentioned above explained that Indian firms are used to handling small-runs, and "We have skilled manpower available cheaply"... [what did he mean by "skilled manpower?"]..."We have tailors who have the ability and the willingness to do complex designs. They have been doing it for years. In China the line workers are industrial workers - not tailors. Their production line needs relatively simple designs that can be easily broken down and mass produced" (Interview, Gokuldas, 2005). The flatter division of labor associated with small operations, short runs and variable designs, has both, created a demand for general-purpose skills at the core of the work organization, as well helped maintain craft-like skills and a generalized design sensibility within a key segment of the apparel workforce. 
But it is precisely these two traits of the Indian apparel sector - namely, the small scales of operation, and the proliferation of the institution of the tailor in the industry's production structure - that have been widely criticized as impeding growth, stunting exports and keeping productivity low (McKinsey 2001, Hashim 2005, Besley and Burgess 2004, Kathuria and Bhardwaj, Elberi, Hertel and Martin 2003). A recent study by McKinsey in fact makes an explicit case that Indian productivity in apparel is sub-par internationally not because Indian apparel firms are unaware of frontier technologies, nor because they do not have access to the latest technology [because a subset of Indian firms have adopted them], but because their scale of operation on average is too small to allow them to profitably adopt these technologies (McKinsey 2001). The McKinsey study further links small scales with the dominance of the tailor in the industry as causes of the sector's low productivity (KcKinsey 2001, Bannerjee and Duflo 2004) - just the opposite of the dynamic outlined above. Clearly, the scale issue operates at multiple-apparently contradictory-levels. The same factor that at one level can be debilitating for productivity growth, can, at another level open up new and quite distinct paths to value addition.

My point here is not to question the importance of raising labor productivity in the Indian apparel sector, nor to dispute the importance of scale. The point rather is to call attention to the contradictory effects of the history of small size and small batch production in Indian apparel, and to argue that alongside the purported down-sides of the small scales of production, this same history has produced important capabilities in the Indian apparel industry, which if nurtured and developed can provide Indian garment firms with a distinctive additional path to upgrading. Currently there is a lot of pressure on Indian apparel firms to increase their production capacities and to scale up to compete with countries like China, especially after the removal of quotas. And indeed, as we saw, the average scale of production of the Indian apparel and textile industry has been going up in the past half decade. While scaling up is important - and is ongoing - India's history of small-batch production simultaneously offers an additional opportunity for firms to capture the benefits that their small runs afford by turning to the production of 
higher value-added, higher quality, customized apparel of complex and variable designs efficiently.

\section{$5.2 \quad$ Scaling up}

That a growing number of Indian textile and apparel firms are leveraging their traditional capacity to handle small runs and variable designs to move toward the flexible production of higher value, customized products, does not mean that Indian textile and apparel firms are not scaling up, or producing for volume-buyers like Wal Mart, or facing the growing pressure on margins by ramping up production volumes. Despite the assumed reluctance of Indian textile and apparel firms to scaling up in the face of India's rigid labor laws and lack of an exit policy, they have invested over $\$ 700$ million in new equipment, new mills and products and expected to spend $\$ 2.5$ billion more by the end of 2005 (Business Week Online, 2004). ${ }^{23}$

The average scale of production in the Indian textile and garment industry has been rapidly inching upward in the decade leading up to the removal of quotas. Three features are striking in this regard: First, it was aided by the progressive liberalization of restrictions on capacity increases by the government starting in the mid-1980s and continuing through the 1990s and early 2000s. As we noted, mean investment per firm in plant and machinery increased significantly throughout the 1990s. Second, there has been significant forward integration by yarn-makers and spinning mills into garments. For example, Arvind Mills, the largest producer of blends and denim in the country and the $3^{\text {rd }}$ largest denim producer globally till recently supplied fabric to virtually every major clothing brand in the world - Levis, Gap, Dockers and so on. Three years ago it, integrated forward into jeans and T-shirts, investing more than $\$ 30$ million in 10 new factories to increase its apparel sales (Interview, Ahmedabad 2005, Business India 2005). The firm has set up several joint ventures in the area of blended fabrics, and has

\footnotetext{
${ }^{23}$ Though a majority of Indian textile and apparel firms have waited till recently to increase capacity in the wake of the removal of quotas - and some are still waiting and watching (Interviews, e.g, Karle Exports, Bangalore 2005), the largest Indian textile firms have made significant investments to increase their scales of operation in recent years.
} 
introduced its own brands in the domestic and export market including 'Ruf-and-Tuf' jeans for the mass domestic market. Raymonds, a Mumbai-based firm, and one of the oldest and largest producers of suiting and shirting fabric in the country, invested in two large, highly sophisticated, state of the art formal suit and bottom's factories in Bangalore in 2003-4. Even before the plants were fully commissioned, Japanese retailers had placed orders for their entire capacity for two years (an unusual development given the low levels of penetration of India's suppliers in the Japanese apparel marker).

Third, there is a growing trend of backward integration by small and medium knitwear and garment exporters into yarn making, and significant investments in the adoption of new technologies by firms at every segment of the value chain. For example, Tiruppur, which has been celebrated for the past two decades as a vibrant small-firm based knitwear export cluster can no longer be considered a predominantly small scale cluster, as the Chairman of the Tiruppur Exporters Association recently noted. "Firms have been aggressively modernizing in the last five years, investing in the latest stitching, pattern making, cutting, embroidery, and dyeing machines. If I buy one CAD machine today it costs me Rs.12.5 million; this itself is me well beyond the investment limit for small scale units. At least 30 garment exporters have set up their own yarn-making mills. The equipment is state of the art, and costly. None of the mills are small in scale. So, Tiruppur is no longer a town of small scale producers - except perhaps some job-working garment converters." ${ }^{24}$ (Interview, Mr. Subramaniam, Tirupur Exporters Association, April 25, 2005).

Finally, firms are investing in what some have called "manufacturing services" (Berger et. al. 1997). Many firms are adopting IT-driven production process control systems, as well as productivity enhancing audits-particularly energy audits. Noting that energy costs generally add up to $11-12 \%$ of total production costs, compared with 6$7 \%$ in direct labor costs, many firms reported in field interviews that the rationalization of

\footnotetext{
${ }^{24}$ By some accounts, about $45-50 \%$ of all the knitwear firms in Tiruppur are converters (Nair, Interview April 28, 2005-many of these may be small in scale, so the disappearance of the small firm may be more illusion than fact.
} 
energy consumption was often the first, and most important step to cutting costs (Interviews, Bangalore 2005, Tiruppur 2002, 2005). Some firms reported savings of up to $30-40 \%$ in energy costs as a result of these measures (Interview Precot Mills, 2002). Many firms have turned to captive gas-fired plants (especially the larger firms such as Gokuldas, Karle, Orient Crafts, Raymonds, Interviews, 2005) while clustered firms such as in Tiruppur, especially in industrial parks, have set up captive and dedicated sources of power.

Rationalization of energy use and attempts to lower energy costs are closely related to automation. Automation, and the deployment of extensive electronic production tracking systems as well as statistical process control systems to monitor work flows, is associated with efforts by apparel and textile firms to raise productivity and lower wastage, cut down-time, reduce rejection rates, as well as to ensure consistency. Automation seems to be as important to firms that produce high volumes-low-margin customers as to those who are investing in design-intensive operations.

In firms that are deploying flexible production systems and are focused on small runs of high value products of variable designs, automation is often skill-enhancing (Applebaum 2004). Even as skill-biased technical change pares down the workforce, the existing workforce needs to be better trained. As mentioned earlier, this is reflected in reports across Tiruppur, Bangalore and Chennai of firms that are paying higher than average wages to retain skilled workers, and where - as in Tiruppur - the fastest growing non-production investment in the region is in the development of the city's training infrastructure (Interview, Chairman, Tiruppur Exporters Association, 2005). In firms such as these where profitability has been rising in recent years, technical change seems to be accompanied by rising wages and greater worker training. In future work it would be useful to compare firms selling to different kinds of buyers with respect to this relationship. Finally, in many cases automation and the adoption of production monitoring technology appears to also be closely associated with the procurement by firms of quality, labor and environmental certifications such as ISO 9000-1, ISO 14000, SA 8000 and the Oekotex label. Though outside the scope of this paper, it is important to 
note that this adoption of global standards has been associated with a market widening and unit value enhancing effect in some emergent strands of the literature on Indian textiles (e.g., Century Mills ) and related sectors (see Robins and Roberts 1997, Schmitz 2004, Debroy 2005, Tewari 2005). The mainstream view however continued to be that stringent international standards often act as non-tariff barriers (RIS Policy briefs 2003).

\section{3 'Customized mass production'}

India's past strengths are shaping in powerful ways the direction of its future comparative advantage - For example, home furnishing and textiles is emerging as a major growth sector of India's exports in the last year, and especially in the first few months after quota removal (See Table 10). This surge in the growth of home furnishings relies in very important ways on the diversity of local fabrics available in India, especially handlooms, cotton, silks and blends. The nurturing of a deeply rooted textiles base in the past, and the strength of cotton in the mix of the India's rich fiber base, are now being leveraged by entrepreneurs who are combining local, high quality fabrics with new designs, novel product development strategies and modern technologies to cater to new export markets.

The example of Himmatsingka Seide Limited (HSL), a Bangalore based top of the line exporter of high-quality silk fabrics and home furnishings illustrates well the dynamics at the high end of this trajectory. HSL was incorporated in 1985 - just after the initial deregulation of the textile industry and at a time when apparel and textile exports were first taking off. HSL is situated in a green-field site on the outskirts of Bangalorea peri-urban location that is becoming the hub of new textile and apparel investments. ${ }^{25}$ HSL is a high value niche player. Though small in terms of sales -- only \$34 million in 2003 -- when compared to the largest textile firms in the country with more than $\$ 350$

\footnotetext{
${ }^{25}$ Most of the new integrated mills and apparel firms employing state of the art technology are located on the fringes of Bangalore -- away from the so-called old centers of textile production (in Mumbai, Chennai and Ahmedabad) or as some put it, away from the sites of the 'old industrial relations'(Interview, Bharatiya International, Delhi 2003). Greenfield sites provide easy access to the local rural workforce, mostly women.
} 
million in sales, it is one of the most profitable companies with operating profit margins consistently between $40 \%-46 \%$ for the last decade (HSL Interview and Annual Report 2005).

Table 10: Post-MFA Growth of India's Textile Exports to the US - Selected Categories

\begin{tabular}{|c|c|c|c|c|c|c|}
\hline \multirow[b]{2}{*}{$\begin{array}{l}\text { SITC } \\
\text { No. }\end{array}$} & \multirow[b]{2}{*}{ Category } & 2004 & $\begin{array}{l}2004 \\
\text { YTD }\end{array}$ & $\begin{array}{l}2005 \\
\text { YTD }\end{array}$ & \multirow{2}{*}{$\begin{array}{c}\text { Percent } \\
\text { Change } \\
\text { YTD2004 } \\
- \\
\text { YTD2005 }\end{array}$} & \\
\hline & & \multicolumn{3}{|c|}{ In 1,000 Dollars } & & \\
\hline 6584 & $\begin{array}{c}\text { Bedlinen (bed, table, kitchen, } \\
\text { toilet) }\end{array}$ & 554,997 & 214,546 & 283,631 & $32 \%$ & $\begin{array}{l}\text { India is } \\
\text { top } \\
\text { supplier; } \\
\text { China is } \\
\text { 3rd }\end{array}$ \\
\hline 6585 & Curtains and home furnishings & 151,397 & 61,576 & 70,007 & $14 \%$ & $\begin{array}{l}\text { India is } \\
\text { 2nd after } \\
\text { China }\end{array}$ \\
\hline 6541 & $\begin{array}{l}\text { Woven fabric of silk and silk } \\
\text { waste }\end{array}$ & 104,061 & 41,453 & 41,916 & $1 \%$ & $\begin{array}{l}\text { India is } \\
\text { top } \\
\text { supplier }\end{array}$ \\
\hline 6589 & $\begin{array}{l}\text { Made-ups (n.e.s.) of textile } \\
\text { materials }\end{array}$ & 80,888 & 32,557 & 35,695 & $10 \%$ & $\begin{array}{l}\text { India } \\
\text { ranks 5th }\end{array}$ \\
\hline 6581 & Packaging materials (textiles) & 26,278 & 7,996 & 13,614 & $70 \%$ & $\begin{array}{l}\text { India is } \\
\text { 3rd } \\
\text { largest }\end{array}$ \\
\hline 6583 & $\begin{array}{l}\text { Blankets and traveling rugs } \\
\text { (not electric) }\end{array}$ & 20,265 & 8,057 & 10,759 & $34 \%$ & $\begin{array}{l}\text { India } \\
\text { ranks 5th }\end{array}$ \\
\hline 6539 & $\begin{array}{l}\text { Woven pile, chenile fabrics of } \\
\text { man-made fibres }\end{array}$ & 13,686 & 6,552 & 8,623 & $32 \%$ & $\begin{array}{l}\text { India is } \\
\text { top } \\
\text { supplier }\end{array}$ \\
\hline & Total - (Above 7) & 951,572 & 372,737 & 464,245 & $25 \%$ & \\
\hline & Others & 691,764 & 283,591 & 315,587 & $11 \%$ & \\
\hline & Total Textiles & $1,643,336$ & 656,328 & 779,832 & $19 \%$ & \\
\hline
\end{tabular}

Source: United States International Trade Commission

HSL has a narrow focus - it focuses predominantly on home furnishings (curtains and upholstery) of silk for the high end export market. ${ }^{26}$ It is almost entirely vertically integrated - apart from filament yarn and silk waste which are imported from China, every aspect of the production process - from the processing of the yarn, to designing and weaving and finishing of the fabric is carried out in-house in a two-million-meters-perannum capacity plant with 115 computerized looms (the largest silk manufacturing facility in India). Yet, despite its integrated facilities, the company's central focus is on

26 HSL's clients include, Jab Joseph Anstoetz, Germany, Zimmer + Rhode, Germany, Christian Fischbacher, Nobilis, France, Ralph Lauren Home and Robert Allen in the US among others 
the design and rapid delivery of small batches of highly customized home-furnishing fabric that fetch high realization rates. With typical runs of $120 \mathrm{~m}$ to $150 \mathrm{~m}$ per customer, HSL's unit values of its custom-designed products are about \$US 20 per meter on average - about 60\% higher than the industry mean (Interview, HSL, 2005 and HSL company documents). These $\$ 20 / \mathrm{m}$ products are retailed at $\$ 100-\$ 120$ by its clients in the EU and US. Ninety percent of these designs are done in-house in what the firm calls its highly technically sophisticated "design kitchen" where the company uses sophisticated process control systems and computerized facilities to mix and match and develop its finely detailed and finished products. The company, with 650 employees, and huge market capitalization of $\$ 160$ million (nearly 5 times its annual sales of $\$ 34$ million) HSL has a portfolio of 20,000 products, and introduces 2000 new products per year, on average. (Interview, HSL, Bangalore, 2005).

Given how heavily the company relies on design skills, quality control and technology, HSL has a highly skilled workforce. HSL's labor costs (total cost to company) are on average 2-4 times higher than the industry norm: Rs.14,000 (\$320) per month for skilled production workers, Rs. 24,000 (\$550) per month for textile engineers, and Rs.12,000 (\$275) per month for the rest of the production workforce. The average wage in the textile industry is Rs. 5-7000 (\$115-\$160) per month at the high end, and $\$ 40-\$ 70$ on average for production workers (Interview HSL, 2005, Company data). Yet, despite high costs, HSL is one of the most profitable firms in the industry as we saw. Its flexible production structure and high position in the value chain, good performance appears to overwhelm its production costs. Ninety percent of the company's product is exported, $48 \%$ to the EU, $34 \%$ to the US and the remainder to other countries.

Resembling a pattern seen in most of the leading textile and apparel firms in the past decade, HSL has recently become inserted in the domestic market. Anticipating a tightening of competition post MFA, and pressure on margins given poor consumer spending in Europe and the US in the past few years, HSL launched its own brand Atmosphere - through five dedicated retail outlets in four of India's largest metros. Its next steps are to open similar stores in high-end market segments of other emerging 
markets - Brazil, Mexico, Hong Kong and others. Its next step involves a move into value added made-ups from fabrics, including high end apparel. It recently entered into collaborations with a high end Italian bed-linen designer and retailer to market brandname designer bed-linen (packaged sets) in top-end specialty stores across Europe (Interviews, HSL, Bangalore, 2005).

At the other end from HSL are companies like Welspun India Limited (WIL) Asia's largest, and the world's fifth largest, Terry towel producer. Both HSL and WIL are vertically integrated companies, but while HSL strenuously distinguishes itself from the Wart Mart model ("we don't sell to Wal Mart; we sell to Ralph Lauren Home"), WIL's aim is to be the largest mass manufacturer of made-ups. It wants to "replace US home-textiles giants Pillowtex and West Point Stevens as the largest home-furnishing manufacturers" and is committed to making the investments that it will take to do so (Asian Textiles Journal, 2005). It is already one of Wal Mart's largest Indian suppliers. A part of the Welspun group of Companies, a diversified business house owned by the Goenka family, WIL began operations in 1985 (the same year that the New Textile Policy was introduced) with a POY texturizing plant. In 1993 it integrated forward into Terry towels; two years later it integrated backwards into cotton spinning; four years later it formed a joint venture with an Italian company to manufacture bathrobes for export markets, and five years after that, in 2004, it set up an integrated bed-sheet/bed-linen project (see Figure 8). A supplier to 12 of the top 20 retailers of the world, its primary buyers are Wal Mart, K-Mart, Target, J.C. Penny, Tommy Hilfiger, Shopko, Calvin Klein, among others-just the opposite of HSL's. In recent years WIL has invested over $\$ 323$ million to increase its capacity from 11,500 tons of towels per year to 24,500 tons per year, and diversify into bed-linen and other made-ups. Just like HSL, it has also launched its own domestic brand, 'Spaces.' In the next three years, alongside exports, it plans to invest nearly $\$ 12$ million to open 125 retail stores across India to market its domestic line of made-ups and bed-sheets (see Business India 2005). 
Figure 8: Welspun group of companies: The trajectory $\mathbf{- 1 9 8 5 - 2 0 0 5}$

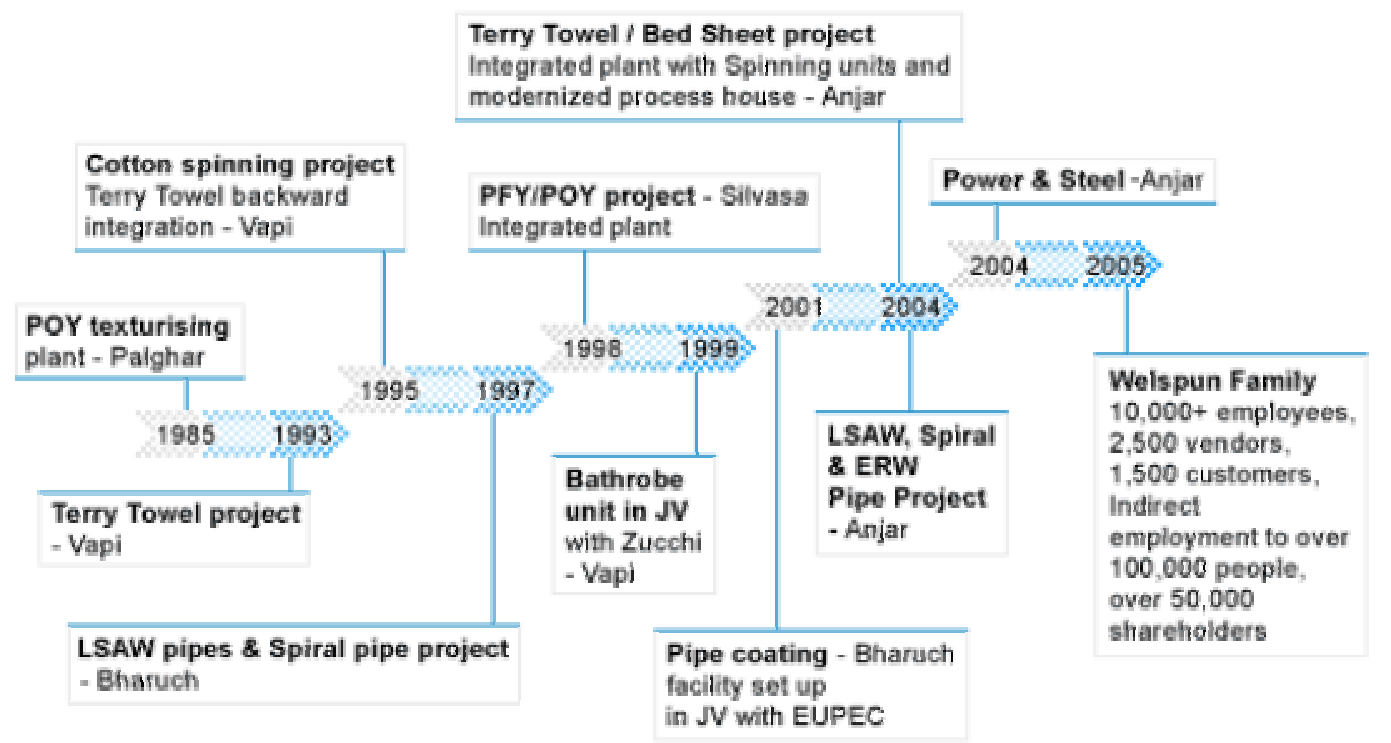

Source: Welspun India Limited - company website

In between firms like these are smaller players whose export and domestic market strategies mirror the diversity that is emerging among India's largest firms. For example, a medium sized Bangalore based exporters of garments (the Choudhury group) used to "produce whatever orders came our way - shirts, pants, kids wear " - till two years ago (Interview, 2005). The company, which has 1500 machines in 10 units of 150 each, followed a 'turnover' based model - low prices, substantial runs, but with neither the massive scales needed to make the 'high turnover low margins' model be profitable, nor the work organization to deal with variable designs, the company changed strategies in the early 2000s. Feeling the pressure on prices and the squeeze margins (which were about $5 \%$ ), the company decided to move out of the turnover business, and into a niche where large volume producers like China and Bangladesh were not threats. It chose fashion-based women's and girls' tops and clothing which had a dominance of handcrafted finishes and operations (embroidery, and other labor-intensive processes). While it modernized and automated some of its production processes (button holding, hemming), it intensified the use of skilled workers overall. The company now produces small batches (not more than 3-5000 per order) of women's fashion-wear for retailers in the EU and US market. The company's profits have risen to $40 \%$, and sales have gone 
up (Interview, Vishal, Chowdhury group, 2005). Its biggest worries are shortages of skilled workers, and high turnover (about 10-15\%) which puts pressure on turn-around times, quality and consistency.

A second example is of a large CMT (cut-make-trim) exporter also based in Bangalore (4000 machines) who similarly pared down its product focus (shirts and bottoms), and turned to automation and design to improve its bottom line. One the one hand, it adopted extensive process control systems and quality circles to track production, cut wastage and improve productivity in its CMT operations; on the other hand it began to explore partnerships with freelance designers in New York to collaborate to design medium-end shirts and bottoms for retailers (such as Dillards and others) - Interview, Karle Group, Bangalore 2005, see also Singhal, 2004, for a general discussion of the evolving structure of Indian apparel supply chains).

Clearly then, the theme of leveraging small production runs, incorporating design, and technology, especially IT-based production services, while scaling up are some of the patterns that cut across the emerging firm strategies in the textile and apparel industry today.

We can now sum up several common patterns run across the recent trajectories of top performers in Indian textiles and apparel exports: (a) a background in textiles, (b) recent forward integration into value added apparel or value added fabrics (technical textiles), (c) strong use of technology, especially software based systems monitoring protocols, and other production and process tracking systems to streamline production, (d) an emergent focus on design (and in some cases product development), (e) and institutional investments in western markets-especially in the strategic purchase of small design and distribution networks in the major markets in the US and EU (See Tewari 2004). Indeed, nearly all the major exporters have rapidly developed a global strategy, involving not just exports, but (modest) overseas investments in asset development (in distribution, design and manufacturing), including technical tie-ups with western partners in the production of the next generation of textile products - 
particularly, high value technical textiles (see Tewari 2004). For example, Madura Garments recently signed a technical collaboration with Outlast Technologies of the US to develop a new range of "smart garments" under the Van Heusen label, including the launch of "cool pants" for the Indian market (Business Standard 2005, Jayaswal 2005).

\section{Blurring of the boundaries between domestic and export markets}

In addition to the patterns above, four additional factors are transforming supplier capacities in ways that are blurring the boundaries between firms producing for the domestic market and those producing for exports. (1) Deepening local capabilities in the area of logistics (warehousing and customized tracking systems), (2) the surprising emergence of design as a source of competitive advantage in Indian apparel; (3) the growing importance of outward-bound investment by Indian apparel firms as a way to counter the exclusion of India from all major regional trade agreements and the advantage of tariff free entry into major markets that many of India's competitors enjoy (Mexico in the US markets, Turkey and Bangladesh in EU market, Eastern Europe and EU enlargement that Indian exporters feel many feel), and (4) a growing focus on domestic brands. In this regard a new development is the increasingly key role that organized retail is playing in structuring the Indian domestic market, reinforced in particular by rising incomes and growing purchasing power among consumers in rapidly growing sectors of the economy such as information technology and business process outsourcing (BPO).

\subsection{Domestic brands, design and retail}

Virtually all the top exporters have introduced their own brands in the domestic market and are aggressively positioning themselves within segments of the domestic market. $^{27}$ They are developing their supply networks, carving out their own distribution networks, seeking distinctive niches and generally staking out their terrain in the domestic market to consolidate their first mover advantage before the government opens up the retail sector to foreign direct investment. Though some domestic clothing brands

\footnotetext{
${ }^{27}$ These trends began about a decade to fifteen years ago. See Tewari (1999).
} 
have been around for decades (e.g, Zodiac, Monte Carlo, Raymonds, Grasim, Vimal), and several franchised foreign brands (especially in men's clothing) had began to surface in the Indian market nearly fifteen years ago (e.g., Van Heusen, Peter England, Lacoste), the rise of domestic brands as an explicit growth strategy began a decade ago with the highly successful launch of Colour Plus, a ready-to-wear mid-market label of the Ambattur Clothing company, a leading exporter of apparel to top end US buyers (Interview, Chennai 2001). Soon after the launch, Raymond's, one of India's foremost textile and apparel companies bought Colour Plus, and popularized it across the country through its dedicated chain of retail stores. A second brand, 'Pantaloon' emerged around the same time, in the same way (see Mukherjee and Patel 2005 for details). Since then, nearly all major exporters and domestic manufacturers have sought to combine a focus of the domestic branded garment segment and an explicit retail strategy. Welspun recently allotted equity shares and warrants ${ }^{28}$ to raise funds for brand development, and retail investments in India as well as international distribution alliances, and plans to open 125 retail stores over the next three years (Business India, 2005; Welspun Annual Report 2005).

Orient Craft, a Delhi based garment exporter also launched an aggressive expansion program to launch its own labels in India and in the US (Goyal 2005). Raymonds recently announced plans to invest in both the backward and forward linked ends of its business. At the back end it is investing $\$ 41$ million to enter into a 50:50 venture with Cotonificio Honegger, a part of Gruppo Zambaitti, a high fashion Italian cotton textile group to make high value shirt fabric, and at the other end has set up two new facilities for US\$ 14 million near Bangalore to produce branded shirts and demin wear (Chatterjee 2005). At the same time it proposes to invest nearly $\$ 0.2$ billion in 2005 to set expand its retail and distribution network within and outside the country - adding more stores under its high end Monzoni brand, increasing its Park Avenue showrooms and "adding 20-30 retail stores every year for the next few years" (Chatterjee 2005, quoting a Raymond's official).

\footnotetext{
${ }^{28}$ At a face value of Rs. 10 and at a premium of Rs. 120 (Business India 2005).
} 
Similarly, Arvind Mills, the large denim producer that recently diversified into jeans, designer T-shirts and casual shirts, not only has developed dedicated brands for its various quality products at different price points, but has developed a novel distribution strategy to retail low-cost jeans to the rural Indian consumer. Its Ruf-n-Tuf line of jeans priced at less than Rs. 300 (\$7), uses the preference among many consumers for hometailored clothes and the ubiquity of tailors across the Indian landscape, to market ready-to assemble kits of jean parts through local tailors that are locally stitched according to the size and specification of the buyer. After going through a period of learning when the brand almost did not survive, the company successfully re-launched its rural brand again in early 2005 (Interveiw, Ahmedabad, January 2005). The rising importance of branded segments in the domestic market combined with the pressure of import-competition, is blurring the boundaries between exports and domestic production in countries with large home markets, such as India. Processes such as these are thus creating demand in the domestic market for the same traits that are valued in demanding export markets.

All of these developments in retail are further being reinforced by the rapid rise of malls across urban India. With the proliferation of malls, the establishment of theme stores, franchises and the rise of hyper-market formats (such as Pantaloons' Big Bazaar), demand for store space for ready made apparel is surging (see Mukherjee and Patel 2005). These shifts in retail are fuelling the demand for good quality and trendy apparel, which is in turn deepening the importance of design in the domestic market. Indeed, the rise of a younger class of middle-class consumers, spawned by the booming BPO and IT sector, has led to burgeoning demand for locally designed, ready to wear clothing in Indian metros. As many recent surveys have noted, with good salaries, strong peer pressure and the growing availability of brands across product categories, spending in retail is being driven by the youth segment in large and mid-sized metros (Bhushan and Anand, 2005). Sales of cellphones, branded garments, high-end jeans, shoes, music systems, bikes and entertainment are driven by new consumers in their early 20 s. As a manager in a mall (Shopper's Stop) recently noted "We see a lot more younger consumers shopping in our stores now. They fall in the 20-25 year bracket, and shop a lot more even though their budgets are relatively smaller" (cited in Bhushan and Anand 
2005, see also Verma 2005). Though this market segment is still relatively small, it has nonetheless provided openings to aspiring designers in India from the demand side.

A new trend observed in recent years is the arrival in India of expatriate and western designers (from France, Italy, UK) who are beginning to form joint ventures with Indian designers to cater to the domestic and export markets (See Tewari 2004). For example, 'Lecoanet India' a France-based apparel design firm headed by an expatriate that had design studios in France and a factory in Latvia, on a trip to India in the late 1990s forged ties with local designers and manufacturers and decided to move the factory from Latvia to India. Then, a few years later, they moved the design center to India "to be closer to the producers;" "Design must cater to the way people work" (Interview, Rewal, New Delhi, 2004). Eventually the company moved its entire staff-one Swiss designer, two Latvians, and one Romanian to India. Currently it is building a "Design Loft" with the help of an Italian consultant, in the Information City technology park, in the heart of the BPO region of Delhi-Gurgaon. (Interview, Rewal, New Delhi 2004).

The broader point here is that there are larger scale effects of these industrial shifts. For example the rise of the BPO and IT sectors - the fastest growing industries in the past decade-is fuelling demand via important income effects for higher value products that is supporting the expansion--indeed creation - of new domestic market segments that are higher value and more skill-intensive. The BPO and IT sector boom has endowed a new, and younger segment of the (urban) workforce with much higher purchasing power than it previously had access to. This segment of the workforce - with particular tastes is fuelling demand for domestic (and overseas) branded apparel at a pace not seen in the home market before. This demand is augmented by the arrival on the scene of retailing formats such as malls that are providing ready outlets for goods catering to this growing market niche. Thus, from the demand side, this preference for higher value apparel, and the growing availability of organized distribution channels through which these products can be marketed is creating the conditions for the rise or development of whole new segments of the apparel industry in India that did not exist before, which in turn can fuel new, higher value capabilities on the supply side, across the 
value chain. Investments by the government two decades ago in institutions such as the National Institute for Fashion Technology, is reinforcing this "market-creating" cycle by generating a supply of skilled local designers who are progressively becoming absorbed in the new cycles of demand.

\section{Conclusions}

This paper examined India's recent integration into the global apparel market to understand alternative forms on global insertion that are occurring, especially in light of the elimination of quotas. The paper made three points. First, it showed that India's (evolving) path to integration in the world market in clothing has been quite different from the experience of many of its competitors. India's trajectory does not fit very well either with neo-liberal arguments about the deregulation of the Indian economy in the early 1990s unleashing the growth potential of Indian apparel (Indian apparel exports took off in the mid-1980s), nor with the trajectories of other successful exporters - e.g. FDI-led integration into vertical clothing chains controlled by dominant global buyers (as in the case of Bangladesh, Sri Lanka, Mauritius, China), or by entry into regional trade agreements with major importing countries (Mexico, Caribbean basin, Eastern Europe and North African countries on the European rim), or by massively scaling up production capacities driven by sustained and deep incorporation into the outsourcing networks of some of the world's leading clothing buyers (China, East and South-East Asia). Though the Indian government is now attempting to attract FDI into textiles, apparel and retail, and domestic firms are scaling up rapidly as well as exploring global partnerships, these features have followed successful integration into export markets, rather than led to it. An understanding of the Indian case thus offers insights into alternative trajectories of upgrading and global integration that do not depend so centrally on prior participation in regional trade agreements, on major FDI, or on deep integration into the world's major clothing value chains.

Second, the paper argued that India's rather quick emergence as a successful textile and garment exporter after years of inward orientation had more to do with 
changes in domestic policy that took place throughout the 1980s and 1990s -- and how these changes interacted with global trade regulations on the one hand, and with ongoing transformations in the Indian domestic market on the other -- than with purely external factors. The internal deregulation of the mid-1980s encouraged a steady build up of domestic investment and induced cycles of technological upgrading within the textile and apparel sector in ways that targeted both exports and the home market. The external sector reforms (trade liberalization) of 1991 deepened some of the trends that deregulation had produced. The strong tier of domestic firms that the earlier reforms had created, are now at the vanguard of India's growing global presence in clothing and textiles. These domestic firms, with their backward linkages into an extensive domestic textile base, have now increasingly transitioned into full package supply and branded manufacturing. These domestic firms are thus playing a stronger role in the internationalization of Indian textiles and apparel than major external drivers such as the role of global buyers, FDI, or preferential trade agreements.

Finally, the paper argued that some of the same factors that account for India's slow integration into global textile and apparel markets have also, indirectly, provided subsets a segment of the industry with opportunities to move along a different, more high road path to upgrading and export growth. The features associated with this growth path are a flexible organization of production that can accommodate small-batches of increasingly design-intensive and higher value product categories. Rapid automation accompanied by a rising demand for skilled workers has put a premium on training which in turn is associated ironically with a tight labor market, better working conditions and higher than minimum wages for a subset of the workers in this labor-intensive sector. As the Indian textile and apparel industry adjusts to the uncertainties of the post-MFA world, an understanding of the diverse paths of adjustment at the firm level is critical. The presence of a strong set of internationally integrated domestic firms, a growing design sensibility, and the emergence of a set of upgrading processes that are not necessarily tied to commoditized labor or deep dependence on footloose global textile value chains is a hopeful finding. 


\section{References}

Abernathy, Frederick H., John T. Dunlop, Janice Hammond, and David Weil. 1999. A Stitch in Time: Lean retailing and the transformation of manufacturing - Lessons from the apparel and textile industry. Oxford: Oxford University Press.

Abernathy, Frederick, Anthony Volpe and David Weil. 2004. "The Apparel and Textile Industries after 2005: Prospects and Choices." Harvard Center for Textile and Apparel Research, Harvard University, Cambridge, MA. Draft.

Appelbaum, Richard. 2005. "The emergence of giant transnational contractors in East Asia: Emergent trends in global supply chains." Mimeo, Department of Sociology, University of California, Santa Barbara.

Asian Textile Journal. 2005. "Welspun sets higher targets.” March. Vol 27.

Bair Jennifer and Gary Gereffi, 2003. "Upgrading, uneven development and jobs in the North American apparel industry." Global Networks 3 (2): 143-169.

Bannerjee, Abhijit and Esther Duflo, 2004. "Growth Theory through the Lens of Development Economics." Forthcoming in the Handbook of Development Economics.

Begg, Bob, John Pickles and Adrian Smith, 2003. "Cutting it: European integration, trade regime, and the reconfiguration of East-Central European apparel production," Environment and Planning A, Vol 23:2191-2207

Berger, Suzanne, David Gartner, and Kevin, Karty. 1997. "Textiles and Clothing in Hong Kong." Chapter 9 in: Made by Hong Kong Edited by Suzanne Berger and Richard Lester. Oxford: Oxford University Press.

Besley, Timothy and Robin Burgess. 2004. "Can Labor Regulations Hinder Economic Performance? Evidence from India.” The Quarterly Journal of Economics. February.

Bhushan, Ratna, and Sanjay Anand. 2005. "The young and restless drive consumerism." Times of India. April 4, 2005

Blustein, Paul, 2004. “Textile Makers Fight for Limits,” Washington Post, October 13.

Blustein, Paul, 2004. "China to Put Export Tax on Clothing, Tariffs to begin on Jan 1 as Quotas Disappear," Washington Post, December 14.

Bradsher, Keith, 2004. "Bangladesh is surviving to export another day," New York Times, December 14, 2004.

Business Alert, 2004. "US firms file petitions to re-apply Textile safeguards," December 16, http://www.tdctrade.com/alert/us0424.htm 
Business India, 2005. Textiles: The brands roll out.” May 9.

Business Line, 2004. "Apparel Exporters to meet in Mumbai for 2-day workshop," December 14.

Business Standard. 2005. "Madura Garments to push smart fabrics.” March 16.

Chatterjee, Somnath, and Rakesh Mohan, 1993. "India's Garment Exports," Economic and Political Weekly 27(35):M95-M118.

Chatterjee, Sumeet, 2005. "Raymond to focus on branded garments segments," Indo Asian News Service, July 31, 2005.

Commission of the European Communities, 2004. "Proposal for a Council Regulation amending Council Regulation (EEC) no.3030/93 and EC no. 3285/94 as regards the common rules for imports of certain textile products from third countries," CEC, Brussels, October 25.

Debroy, Bibek. 2005. "The SPS and TBT Agreements - Implications for Indian Policy," ICRIER Working Paper No. 163, Indian Council for Research on International Economic Relations, New Delhi.

DeLong, Bradford J. 2003. 'India,' Chapter ? In: In Search of Prosperity: Analytic Narratives on Economic Growth, Edited by Rodrik et. al. Princeton University Press.

Economic Times, 2005. "Indian labor costs are lowest." April 12, 2005.

Elbehri, Aziz, Thomas Hertel and Will Martin. 2003. "Estimating the impact of WTO and Domestic Reforms on the Indian Cotton Industry." Review of Development Economics 7(3): 343-359.

Feenstra, R.C., 1998. "Integration of Trade and Disintegration of Production in the Global Economy," Journal of Economic Perspectives, 12 (4):31-50

Financial Times, 2004, July 19, pp. 11 cf. Gereffi 2004.

Gangopadhyay, Subhashish and Shagun Krishnan. 2005. "Churning in Indian Industry: Cases of Textiles and Electrical Machinery in the Eighties and the Nineties," India Development Foundation, Presentation.

Ghosh, Santanu, 2005. "Post-quota, Textile Inc shoots from the wallet," Indian Express, April 1.pp. 11.

Gereffi, Gary, 1999. "International Trade and industrial upgrading in the apparel commodity chain," Journal of International Economics 48(1):37-70. 
Gereffi, Gary and R. Kaplinsky (eds), 2001. Special Issue on The Value of Value Chains, IDS Bulletin Vol 32, No. 3. Sussex.

Gereffi, Gary, D. Spenner and J. Bair (eds.) 2002. Free Trade and Uneven Development: The North American Apparel Industry after NAFTA. Philadelphia: Temple University Press.

Gereffi, Gary, 2004. Industrial adjustment in the North Carolina Textile and Clothing Industry, Presentation at the Global Apparel/Clothing Europe Conference at the University of North Carolina at Chapel Hill, October 15-16, 2004.

Gereffi, Gary, 2004. Europe and Global Value Chains, Presentation at the Global Apparel/Clothing Europe Conference at the University of North Carolina at Chapel Hill, October 15-16, 2004.

Gibbon P, 2000. "Back to the basics through delocalization: the Mauritius garment industry at the end of the $20^{\text {th }}$ century," Copenhagen, Center for Development Research, Working Paper 00.07.

Goyal, Malini. 2004. “Dressing up for 2005.” India Today, December 17.

Hashim, Danish, 2005. "Making the Textile Industry competitive after MFA," Economic and Political Weekly, Vol. XL No. 2, January 8-14, p. 117-127.

Himmatsingka Seide. 2004, 2005. Company documents, mimeos. Bangalore.

Humphrey, John and Hubert Schmitz, 2000. "Governance and upgrading: linking industrial cluster and global value-chain research," IDS Working Paper No. 120, Institute of Development Studies, University of Sussex, Brighton.

International Labour Organization. 2003 (Reprinted; original 2002). Garment Industry in South Asia: Rags or Riches? ILO.

Jayaswal, Rajeev. 2005. "Textiles + Tech $=$ Premium.” Economic Times, May 7.

Kathuria, Sanjay, Will Martin and Anjali Bharadwaj, 2001. Export Quotas and Policy Constriants in the Indian Textile and Garment Industries, World Bank, Washington D.C.

Knappe, Matthias, 2003 "Textiles and clothing: what happens after 2005?" International Trade Forum, Issue 2/2003, International Trade Center, page 16, http://www.tradeforum.org/news/fullstory.php/aid/550/Textiles_and_Clothing:_What_Happens_After_200 $\underline{5 . h t m l}$

Lall, Sanjaya, et. al., 2004. "Mapping fragmentation,” Oxford Development Studies.

Majumdar, Pallavi, 2005. "Textile firms spin profits in quota-free world," The Business Standard, February 16, p. 2. 
McKinsey Global Institute, 2001. "Apparel” in the Report, India: the Growth Imperative, McKinsey Global Institute.

Ministry of Industrial Policy and Promotion, 2005. Secretariat for Industrial Assistance, Vol. XIII, No. 9, Government of India, New Delhi, January.

Ministry of Textiles, Government of India, 1999, Report of the Expert Committee on Textile Policy, Government of India, Udyog Bhavan, New Delhi. August.

Ministry of Textiles, Government of India, 2005, http://texmin.nic.in/

Ministry of Textiles, Government of India, 2005. “Annual Report, 2004-2005," and “Annual Report 2003-04,” http://texmin.nic.in/annualrep/ar05_con.htm

Mukherjee, Arpita and Nitisha Patel. 2005. FDI in retail sector in India. Academic Foundation, New Delhi, India.

Mukherkee, Shubham. 2005. "S Kulars to pump in Rs. 300 crore to revamp wardrobe." Economic Times, April 9, 2005.

Nordås, Hildegunn Kyvik. 2004. "The Global Textile and Clothing Industry post the Agreement on Textiles and Clothing." Discussion No. 15, World Trade Organization, Geneva, Switzerland.

Palpeceur F., et. al., 2005. "New challenges for developing country suppliers in global clothing chains: A comparative European perspective" World Development (In press).

Pickles, John, 2002. "Gulag Europe? Mass Unemployment, New Firm Creation, and Tight Labor Markets in the Bulgarian Apparel Industry." Pp 246-272 in Work, Employment, and Transition: Restructuring Livelihoods in Post-Communism. Ed. A. Rainnie, A. Smith, and A. Swain. London: Routledge.

Ramaswamy, K.V. and Gary Gereffi, 1998. "India's Apparel Sector in the Global Economy: Catching Up or Falling Behind?" Economic and Political Weekly 33 (3):122130.

RIS Policy Briefs, 2003. Cancun Agenda: Environmental Requirements and Developing Countries, RIS Policy Brief, No, 5, June. New Delhi.

Robins, N and S. Roberts (eds). 1997. Unlocking Trade Opportunities: Case Studies of Export Success in Developing Countries. International Institute of Environment and Development. Report comissioned by the United Nations Department of Policy Coordination and Sustainable Development. (http://www.iied.org/smg/pubs/unlock.html. 
Roy, Tirthankar, 1998. "Economic Reforms and Textile Industry in India," Economic and Political Weekly 33(32):2173-2182.

Schmitz, Hubert (ed). 2004. Local Enterprises in the Global Economy: Issues of Governance and Upgrading. Edward Elger: Cheltenham.

Singhal, Arvind, et. al. 2004. "Creating and Preserving Value in the Textile and Apparel Supply Chain: From Fibre to Retail." Textile Outlook International, January-February 2004. p. 135-156.

Smith, Adrian, et. al. 2004. "Upgrading the East European Apparel Industry: Outsourcing and the "Embedded Geographies' of Production," Paper presented at the conference, "Clothing Europe: Comparative Perspectives on Trade Liberalization and Production Networks in the New European Clothing Industry," University of North Carolina at Chapel Hill, NC October 15-16.

Subramaniam, G. Ganapathy, 2005. "Garment exporters facing tough post-MFA bargain,” The Economic Times, New Delhi, February 16.

Surender, T, 2004. "The big factories are coming," Businessworld, November 15.

Tewari, M, 1999. "Successful Adjustment in Indian Industry: The Case of Ludhiana's Woolen Knitwear Industry." World Development, Vol. 27, No. 9.

Tewari, M, 2002. "The Challenge of Reform: How Tamil Nadu's Textile and Apparel Industry is Facing the Pressures of Liberalization," Paper prepared for the India Program, Center for International Development, Harvard University.

Tewari, M, 2003. "Engaging the Dragon: The emerging dynamics of inter-regional trade and investment between India and China." Draft paper prepared for the South Asia Program, Columbia University's Earth Institute and the Ministry of Commerce, India. July.

Tewari, M, 2004. "Regional repositioning within India's garment industry: Elements of a third generation narrative in global commodity chains,' Draft, October 14.

Tewari, M and Poonam Pillai. 2005. "Global Standards and the Dynamics of Environmental Compliance in India's Leather Industry" Oxford Development Studies 33 (2): 245-267.

The Hindu. 2005. "Raymond to invest Rs. 280 crore in joint venture, capacity expansion. February 18.

Times News Network, 2005. "Welspun plans to increase domestic presence." Times of India, May 7, 2005.

UNCTAD. 2005. TNCs and the Removal of Textiles and Clothing Quotas. Current Studies in FDI and Development, UNCTAD, New York and Geneva. 
US ITC, 2004. Textiles and Apparel: Assessment of the Competitiveness of Certain Foreign Suppliers to the US Market, Washington D.C., Report declassified in January 2004.

Verma, Pragati. 2005. "BPO babies jam malls on Uncle Sam's b'day." Economic Times, July 5.

Verma, Samar. 2002. "Export Competitiveness of the Indian Textile and Garment Industry," Working Paper No. 94, ICRIER, Indian Council for Research on International Economic Relations New Delhi.

Virmani, Arvind, 2004. "Economic Reforms: Policy and Institutions - Some lessons from Indian reforms." ICRIER Working paper No. 121, Indian Council for Research on International Economic Relations, New Delhi.

Welspun Company website 2005. www.welspun.com

World Bank. 2000. India Cotton and Textile Industries Reforming to Compete. New Delhi: Allied Publishers. 